\title{
UPPER CRETACEOUS TO PALEOGENE FORBULGE UNCONFORMITY ASSOCIATED WITH FORELAND BASIN EVOLUTION (KRAS, MATARSKO PODOLJE AND ISTRIA; SW SLOVENIA AND NW CROATIA)
}

\author{
ZAKRASELA PERIFERNA IZBOKLINA POVEZANA Z RAZVOJEM \\ ZGORNJEKREDNO-PALEOGENSKEGA PREDGORSKEGA \\ BAZENA; KRAS, MATARSKO PODOLJE IN ISTRA \\ (JZ SLOVENIJA IN SZ HRVAŠKA)
}

\author{
Bojan OTONIČAR ${ }^{1}$
}

\begin{abstract}
UDC 551.44.551.7(497.4-14)

552.541.551.7(497.4-14)

Bojan Otoničar: Upper Cretaceous to Paleogene forbulge unconformity associated with foreland basin evolution (Kras, Matarsko Podolje and Istria; SW Slovenia and NW Croatia)

A regional unconformity separates the Cretaceous passive margin shallow-marine carbonate sequence of Adriatic Carbonate Platform from the Upper Cretaceous and/or Paleogene shallow-marine sequences of synorogenic carbonate platform in southwestern Slovenia and Istria (a part of southwestern Slovenia and northwestern Croatia). The unconformity is expressed by irregular paleokarstic surface, locally marked by bauxite deposits. Distinctive subsurface paleokarstic features occur below the surface (e.g. filled phreatic caves, spongework horizons...). The age of the limestones that immediately underlie the unconformity and the extent of the chronostratigraphic gap in southwestern Slovenia and Istria systematically increase from northeast towards southwest, while the age of the overlying limestones decreases in this direction. Similarly, the deposits of synorogenic carbonate platform, pelagic marls and flysch (i.e. underfilled trinity), deposits typical of underfilled peripheral foreland basin, are also diachronous over the area and had been advancing from northeast towards southwest from Campanian to Eocene. Systematic trends of isochrones of the carbonate rocks that immediately under- and overlie the paleokarstic surface, and consequently, of the extent of the chronostratigraphic gap can be explained mainly by the evolution and topography of peripheral foreland bulge (the forebulge). The advancing flexural foreland profile was the result of vertical loading of the foreland lithospheric plate (Adria microplate) by the evolving orogenic wedge. Because of syn- and post-orogenic tectonic processes, and time discrepancy between adjacent foreland basin deposits and tectonic ("orogenic") phases it is difficult to define the exact tectonic phase responsible for the evolution of the foreland complex. According to position and migration of the subaerially exposed forebulge, distribution of the foreland
\end{abstract}

Izvleček

UDK 551.44.551.7(497.4-14)

552.541.551.7(497.4-14)

Bojan Otoničar: Zakrasela periferna izboklina povezana $z$ razvojem zgornjekredno-paleogenskega predgorskega bazena; Kras, Matarsko podolje in Istra (JZ Slovenija in SZ Hrvaška) $\mathrm{V}$ jugozahodni Sloveniji in Istri so kredna karbonatna zaporedja Jadranske karbonatne platforme pasivnega obrobja Jadranske mikroplošče ločena $\mathrm{z}$ regionalno diskordanco od zgornjekrednih in paleogenskih karbonatnih zaporedij sinorogene karbonatne platforme. Razgibano paleokraško površje, ki diskordanco označuje, je lokalno prekrito z boksitom. Pod površjem se pojavljajo različne podpovršinske paleokraške oblike, med drugim večje zapolnjene freatične jame in diskretni horizonti drobnih prepletajočih se kanalčov. Starost apnencev neposredno pod paleokraškim površjem in obseg stratigrafske vrzeli v jugozahodni Sloveniji in Istri sistematično naraščata od severovzhoda proti jugozahodu, nasprotno pa starost apnencev, ki paleokraško površje pokrivajo v tej smeri upada. Preko obravnavanega območja so med campanijem in eocenom od severovzhoda proti jugozahodu napredovala tudi sedimentna zaporedja sinorogenih karbonatnih platform (karbonatne kamnine Kraške grupe) ter pelagičnih laporjev in fliša, ki predstavljajo sedimente podhranjenega predgorskega bazena. Sistematične trende izohron karbonatnih kamnin, ki ležijo neposredno pod in nad paleokraškim površjem in posledično razpona stratigrafske vrzeli lahko $\mathrm{v}$ veliki meri razložimo $\mathrm{z}$ evolucijo in topografijo periferne predgorske izbokline. Napredujoči fleksurni predgorski profil je nastal zaradi vertikalne obremenitve predgorske litosferske plošče (Jadranske mikroplošče) z nastajajočim orogenim klinom. Zaradi sočasnih in postorogenih tektonskih procesov ter časovnega neskladja med sedimenti sosednjih predgorskih bazenov in med različnimi tektonskimi (»orogenimi«) fazami tega dela zahodne Tetide $\mathrm{v}$ kredi in paleogenu, je opredelitev tektonske faze, ki je neposredno odgovorna za evolucijo obravnavanega predgorja otežena. Glede na položaj in migracijo periferne iz-

${ }^{1}$ Karst Research Institute ZRC SAZU, Titov trg 2, Si-6230 Postojna, Slovenia, e-mail: otonicar@zrc-sazu.si

Received/Prejeto: 01.02.2006 
related macrofacies and orientation of tectonic structures, especially of Dinaric nappes, and Dinaric mountain chain I suggest that the foreland basin complex in western Slovenia and Istria was formed during mesoalpine ("Dinaric") tectonic phase due to oblique collision between Austroalpine terrane/Tisia microplate and Adria microplate when probably also a segmentation of the foreland plate (Adria microplate) occurred.

Key words: forebulge unconformity, paleokarst, chronostratigraphic gap, flysch, Adriatic Carbonate Platform, synorogenic carbonate platform, foreland basin, Adria microplate, Dinaric orogene, Cretaceous, Paleogene, SW Slovenia, Istria. bokline, razporeditev makrofaciesov podhranjenega predgorskega bazena ter usmerjenost tektonskih struktur, predvsem Dinarskih pokrovov, in Dinarskega gorstva v celoti domnevam, da je nastal predgorski sistem v zahodni Sloveniji in Istri med mezoalpidsko (»Dinarsko«) tektonsko fazo, kot posledica bočne kolizije med Avstroalpidskim terranom in/ali Tisa mikroploščo ter Jadransko mikroploščo, pri čemer je verjetno prišlo tudi do segmentacije Jadranske mikroplošče.

Ključne besede: diskordanca, paleokras, kronostratigrafska vrzel, fliš, Jadranska karbonatna platforma, periferna predgorska izboklina, sinorogena karbonatna platforma, predgorski bazen, Jadranska mikroplošča, Dinarski orogen, kreda, paleogen, jugozahodna Slovenija, Istra.

\section{INTRODUCTION}

Plate tectonics theory had a crucial impact on our understanding of sedimentary basins, and consequently, of carbonate sedimentary systems. Plate tectonics determines not only the gross architecture (dimension and shape) and lithological/structural characteristics of carbonate platforms (Bosellini, 1989), but also their evolution and the longevity. Those characteristics are largely defined by specific geotectonic setting in which certain carbonate platform begin to grow. Carbonate platform(s), which colonize certain area through longer or shorter period of geologic history, constantly change its/their position in relation to the equator and plate boundaries and pass through different phases of the Wilson cycle. The sedimentary and diagenetic character of the carbonate platform(s) constantly change(s) during this journey and at a stretch, the platform evolution may be stoped. In this case, the area formerly inhabited by the carbonate platform may fall under conditions which are not favourable for considerable carbonate production. In one scenario it may immediately after the deposition or later in the geologic history be uplifted, subaerially exposed and karstified. Similarly as the plate tectonics governs the sedimentary evolution of the carbonate platforms, it may also determins their diagenetic evolution, including karstification. The gross architecture, lithological/structural caharacteristics, and the evolution and the longevity of the uplifted area with subaerially exposed carbonate platform are mainly dependent on its geotectonic position regard to plate boundaries, former geodynamics and consequently topography of the area, especially of the carbonate platform. Although important for the appearance of the karstic landscape, the effects of other variables, such as climate and ground water level, may be just superimposed on the geotectonically predisposed framework.
Each karstic landscape carries its specific geotectonic signature which can be read from and explained with specific evolution of karstic features and a karst system as a whole. In addition, studies of sedimentary successions of rocks that under- and overlie the (paleo-) karstic surface and that of the adjacent sedimentary basins as well as the general geologic conditions of the region may significantly improve our knowledge on geodynamics of the uplifted area.

The paper documents an example of paleokarst that occurred during the uplift of the Adriatic Carbonate Platform (sensu Vlahović et al., 2005) in the distant foreland region of the evolving collision related orogenic belt between the Adria microplate (sensu Stampfli et al., 1998) and the Austroalpine terrane and/or Tisia microplate (sensu Neugebauer et al., 2001) in the Late Cretaceous and the Early Paleogene.

The study is based on 36 geological profiles from the karstic regions of southwestern Slovenia, both Slovenian and Croatian part of Istria peninsula and the area between Trieste bay and Italian-Slovenian border in northeastern Italy (Figs. 1, 2). To get a whole picture of conditions that dominated the region during the emersion period, I expend the area of interest to synorogenic carbonate platform that onlap the paleokarstic surface and to siliciclastic flysch regions of afore mentioned areas and the adjacent regions of western Slovenia and northeastern Italy (along the border between Italy and Slovenia).

The aim of this work is to show the causes of the uplift and subaerial exposure of the northwestern part of the Cretaceous Adriatic Carbonate Platform in Late Cretaceous and Early Paleogene. The data presented here were provided mainly from the studies of paleogeographic and topographic extent of the emersion, stratigraphy of the carbonate successions that immediately under- and 


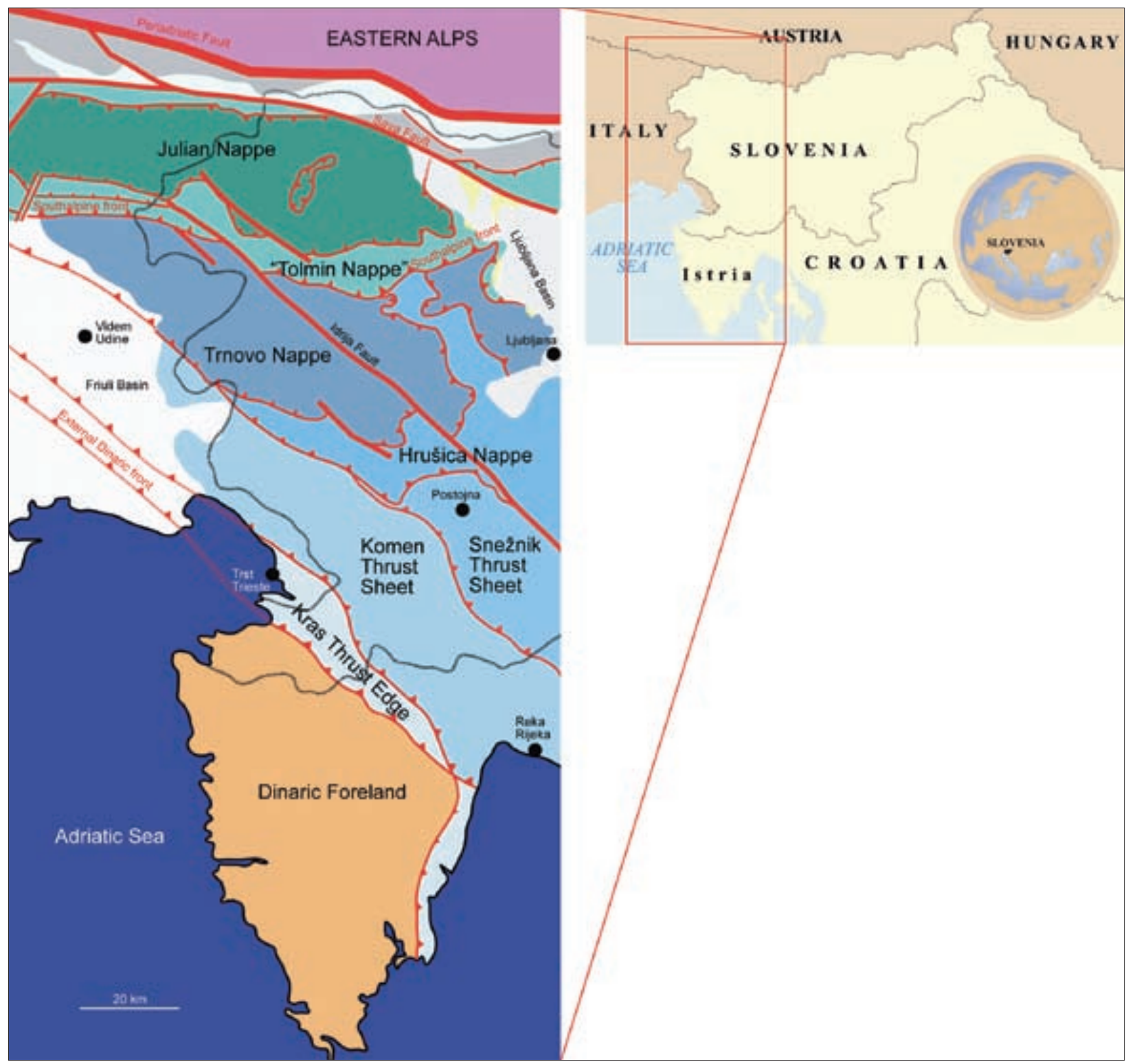

Fig. 1: Geographical position and simplified geological map of the western Slovenia and Istria showing major structural elements (modified from Placer, 1999).

overlain the paleokarstic surface, stratigraphy and sedimentology of the onlapping synorogenic carbonate platform and adjacent deeper marine basin as well as from regional geotectonic and general geologic situation. The time of the uplift is correlated with events on the adjacent plate boundaries of the western Tethian domain (traditional "orogenic phases") and global eustatic curve.

\section{GEOLOGY OF THE AREA}

The geology of southwestern Slovenia and Istria has been studied from the late $19^{\text {th }}$ century on. Since that time also a regional unconformity which separates shallow-marine carbonate successions of different Cretaceous formations from shallow-marine limestones of the Upper Cretaceous/Lower Paleogene Liburnia Formation or Eocene 


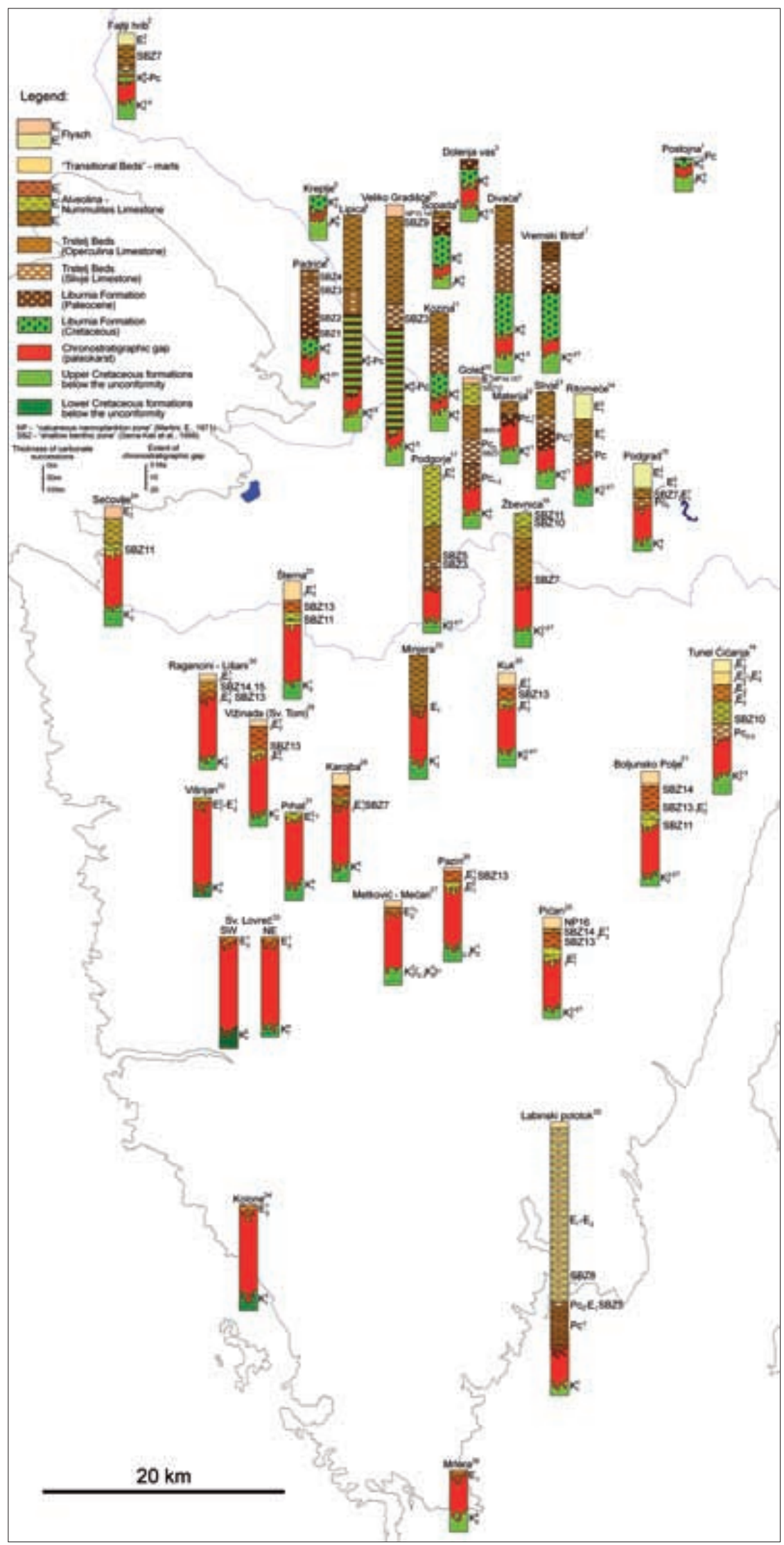

Fig. 2: Simplified lithostratigraphic columns of Cretaceous to Eocene successions in southwestern Slovenia and Istria (NW Croatia and SW Slovenia), with one column from NW Italy. Authors of original geological columns are listed below:

1) Šribar (1995); Rižnar (1997), 2) Drobne (1977, 1979), 3) Drobne et al. (1988, 1996); Šribar (1995); Jurkovšek et al. (1996), 4) Jurkovšek et al. (1996), 5) Drobne (1981); Jurkovšek et al. (1996), 6) Jurkovšek et al. (1997), 7) Hamrla (1959); Drobne (1977, 1979); Pavlovec et al. (1991), 8) Hamrla (1959, 1960); Jurkovšek et al. (1996), 9) Brazzatti et al. (1996), 10) Hamrla (1960); Drobne et al. (1991); Jurkovšek et al. (1996), 11) Hamrla (1959); Buser \& Lukacs (1979); Delvalle \& Buser (1990); Jurkovšek et al. (1997); this study, 12) Drobne (1977); Delvalle \& Buser (1990), 13) Delvalle \& Buser (1990); Šribar (1995); Buser \& Radoičić (1987), 14) Šikić et al. (1972); Drobne (1977), 15) Drobne (1977); this study, 16) Drobne (1977, 1981); Hottinger \& Drobne (1980); Drobne \& Pavlovec (1979); Drobne et al. (1991); Turnšek \& Drobne (1998); this study, 17) Drobne (1977), 18) Šikič et al. (1972); Drobne (1977), 19) Biondić et al. (1995), 20) Šikić et al. (1972); Drobne (1977), 21) Šikić et al. (1968); Drobne (1977), 22) Pleničar et al. (1969); Drobne (1977); Gabrić et al. (1995), 23) Pleničar et al. (1969); Drobne (1977), 24) Hamrla (1959); Pleničar et al. (1973); Drobne (1977); Velić \& Vlahović (1994); Matičec et al. (1996), 25) Šikić et al. (1968); Drobne (1977); Hottinger \& Drobne (1980); Drobne et al. (1991), 26) Matičec et al. (1996), 27) Tarlao et al. (1995), 28) Buser \& Lukacs (1972); Drobne (1977); Hottinger \& Drobne (1980); Matičec et al. (1996), 29) Polšak \& Šikić (1973); Drobne (1977), 30) Drobne et al. (1991), 31) - 34) Matičec et al. (1996), 35) Šikić et al. (1968); Magaš (1973); Šikić et al. (1973); Šikić \& Polšak (1973); Höttinger \& Drobne (1980); Otoničar et al. (2003), 36) Polšak (1970); Drobne (1977); Matičec et al. (1996). 
Alveolina-Nummulites Limestone has been known. The Liburnia Formation, Alveolina-Nummulites Limestone and intermediate Trstelj Beds represent the Kras Group (Košir, 2003) (Fig. 3), which corresponds to the lower unit of the underfilled peripheral foreland basin stratigraphy (i.e. the lower unit of the "underfilled trinity" of Sinclair, 1997). Thus the unconformity represents a megasequence boundary and typically separates the underlying passive margin carbonate succession from the overlying deposits of the synorogenic carbonate platform at periphery of the foreland basin (Košir \& Otoničar, 2001). The synorogenic carbonate platform was finally buried by prograding hemipelagic marls (i.e. the middle unit of the "underfilled trinity" of Sinclair, 1997) and deep-water clastics (flysch) (i.e. the upper unit of the "underfilled trinity" of Sinclair, 1997) (Fig. 3). Because the name of the carbonatre platform that overlie the unconformity has not been defined yet, I will use in this paper only the general geodynamic term - i.e. the synorogenic carbonate platform.

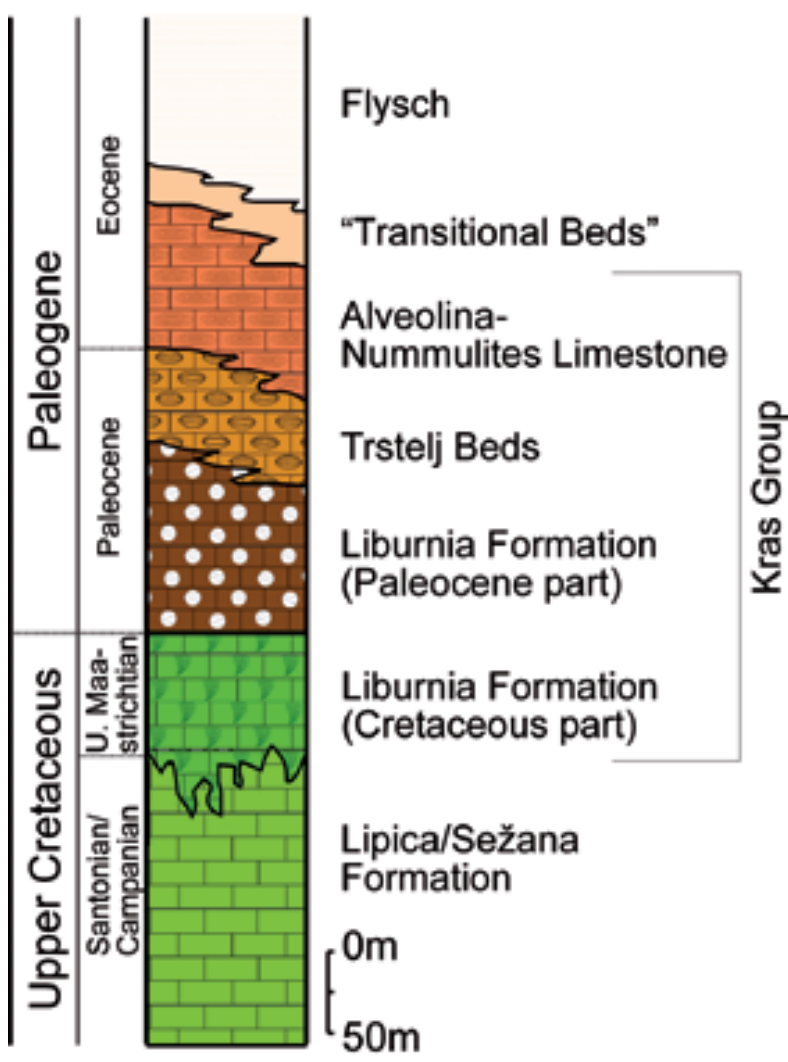

Fig. 3: Generalized stratigraphic column of Upper CretaceousEocene succession in the Kras (Karst) and Matarsko podolje regions, SW Slovenia, showing major lithostratigraphic units (modified from Košir, 2004).

The unconformity is expressed by an irregular paleokarstic surface, locally marked by bauxite depos- its. Although the unconformity has been repeatedly mentioned, no systematic study of paleokrast has been performed. Relatively numerous papers on biostratigraphy, especially on the carbonate successions of the Kras Group, have been published (see list of references attached to Fig. 2), yet not more than few attempts on explanation of the sedimentology of the paleokarstic deposits and onlapping beds have been done (Otoničar, 1997; Debeljak et al., 1999; Durn et al., 2003). Only occasionally, the geotectonic conditions under which the paleokarst (uplift) evolved have been briefly mentioned (Košir \& Otoničar, 2001; Otoničar \& Košir, 2001; Durn et al., 2003).

Tectonically, the discussed area corresponds to three macrotectonic units, the Southern Alps, the Ex-

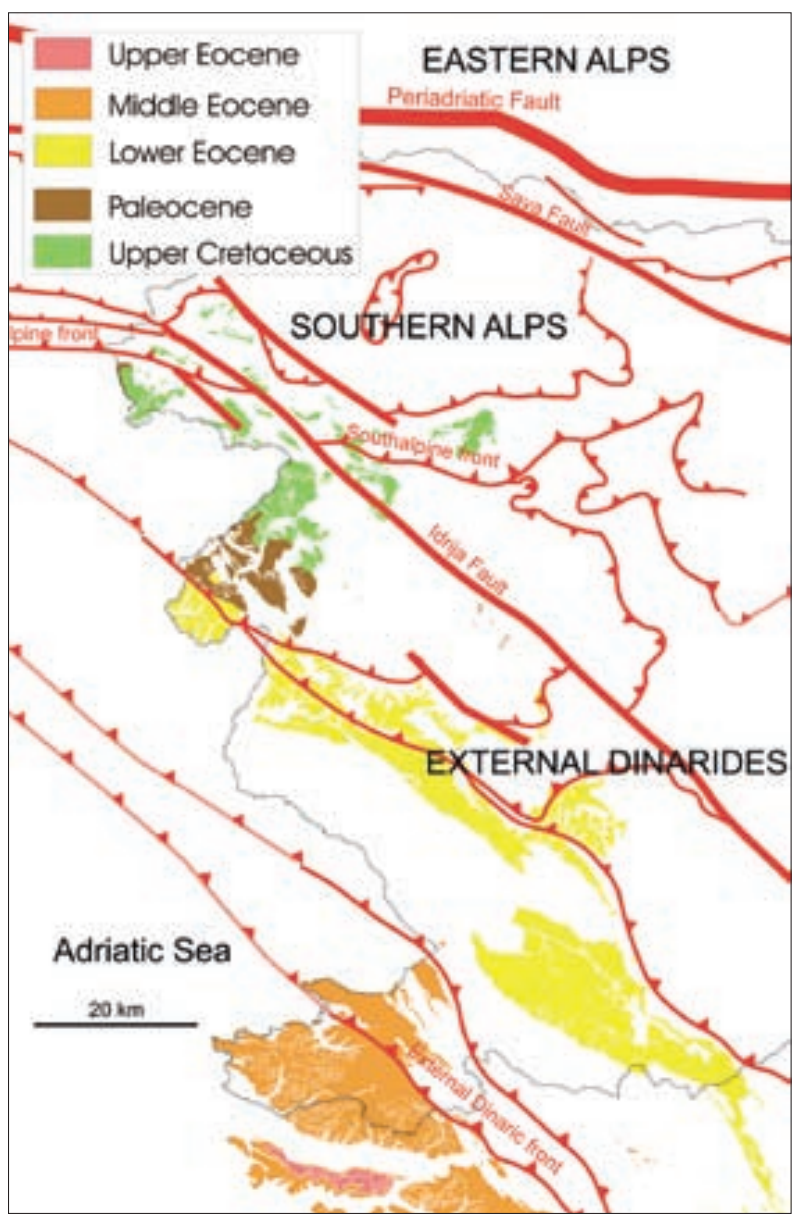

Fig. 4: Illustrative geological map showing distribution of flysch deposits and major structural elements in western Slovenia. The map is based mainly on data from basic geological maps of Yugoslavia, 1:100.000, sheets Beljak \& Ponteba (Jurkovšek, 1986), Udine-Tolmin \& Videm (Udine) (Buser, 1986), Kranj (Grad \& Ferjančič, 1974), Gorica (Buser et al., 1968), Postojna (Buser et al., 1967), Trst (Pleničar et al., 1969) and Ilirska Bistrica (Šikić et al., 1972). Copyright: Geološki zavod Slovenije (Geological survey of Slovenia), 2002 - All rights reserved. 


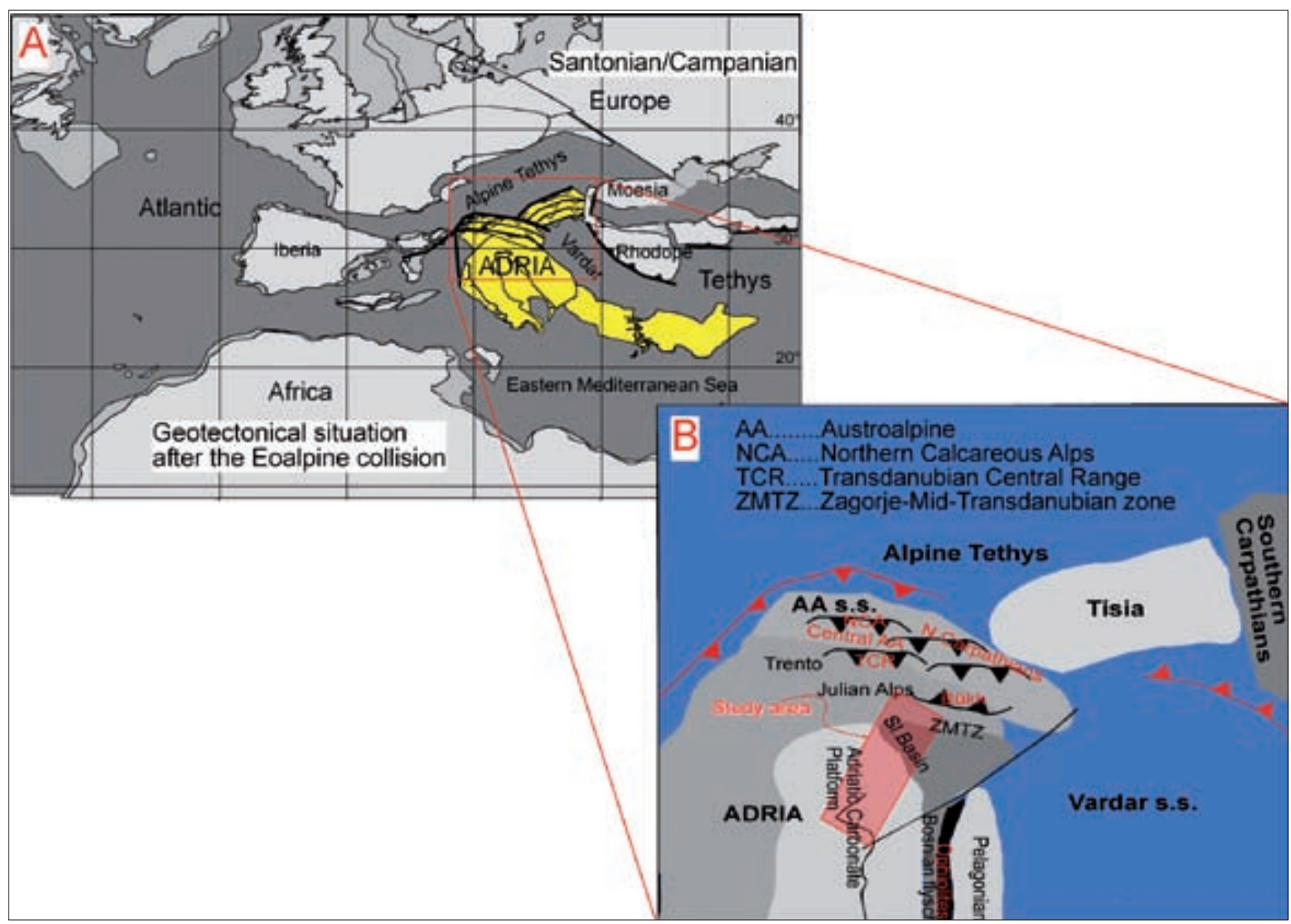

Fig. 5: A) Paleogeographical map showing major geotectonic units at Santonian-Campanian boundary in western Tethys and central Atlantic (modified from Neugebauer et al., 2001). B) Geotectonic and paleogeographic units of Adria microplate and adjacent areas.

ternal Dinarides and the Dinaric foreland (Placer, 1999) (Fig. 1). While the flysch-related sediments can be followed across the all three units (Fig. 4), the unconformity and the overlying carbonate successions of the Kras Group correspond to the most external thrust unit of the Dinaric fold and thrust belt - the northwestern External Dinarides in southwestern Slovenia, Italian part of the Kras plateau and northeastern Istria, and to more stable foreland domain of the Dinaric mountain belt in other parts of Istria (Figs. 1, 2).

The nappe structure of northwestern part of the External Dinarides comprises five successively lower and younger thrust units from northeast to southwest: Trnovo Nappe, Hrušica Nappe, Snežnik Thrust Sheet, Komen Thrust Sheet and Kras Thrust Edge (Placer, 1981, 1999, 2002) (Fig. 1).

The External Dinarides and the Dinaric foreland correspond to the northwestern part of the Cretaceous Adriatic Carbonate Platform and the Upper CretaceousEocene synorogenic carbonate platform which occupied northeastern part of the Adria microplate s.s. (Fig. 5). In the Cretaceous the area of present day Southern Alps was a part of deeper marine realm which comprised the Slovenian Basin formed in the Middle Triassic (Cousin, 1981; Buser, 1989) and the area of former Julian Carbonate Platform which was drowned in the Lower and Middle Jurassic (Cousin, 1981; Buser, 1989).

The geologic and paleogeographic situation started to change severely in the Late Cretaceous (see below). It is important to note, that the described region is recently confined from the north side by the Periadriatic fault zone, from the west by the deposits of the Southern Alpine Molasse Basin and from the south and southwest by the Adriatic Sea and its sediments (Fig. 1).

To understand the mechanisms that governed the uplift and emersion, regional geotectonic conditions of the wider area of the Late Cretaceous-Early Paleogene Western Tethys were taken into consideration.

During the Mesozoic, the area between Eurasia and Gondwana or the western part of the extensive Tethys bay of the Pangea was occupied by more or less uniform Adria microplate surrounded by smaller tectonic units or terranes (Fig. 5). With regard to major geotectonic events, the extent and shape of Adria microplate was 
changing constantly through the geologic history. The results of these events (e.g. tecto-sedimentary successions or cycles) could be correlated between geographically and geologically distant parts of the Adria microplate.

After substantial Permian to Middle Triassic and Triassic/Jurassic extensional tectonics, the Adria domain became encircled by oceanic bays and dissected by numerous deepwater basins and drowned carbonate platforms (Fig. 5). It is considered that since Early Jurassic the Adriatic Carbonate Platform had been isolated by deeper marine realms (Vlahović et al., 2005).

At the Middle/Late Jurassic boundary compressional tectonic regime prevailed over the peri-Adriatic region. It was caused by the beginning of closure (subduction) of the adjacent oceanic bays of the Western Tethys. During the Late Jurassic and Cretaceous gentle broad-scale positive and negative lithospheric deflections periodically occurred on the Adriatic Carbonate Platform. The deflections were expressed by coexistence of karstic areas and somewhat deeper marine intra-platform basins (Tišljar et al., 1995; 1998; Vlahović et al., 2005). Distinctive deflections correspond to period of ophiolite emplacement [e.g. the Late Jurassic/Early Cretaceous obduction of ophiolite suite of the Dinaric Tethys on the E margin of the Adria microplate (Pamić et al., 1998; 2000)] and distant collisions [e.g. the mid-Cretaceous Eoalpine orogenesis in the Pelso/Austroalpine/Tisia domain (Faupl \& Wagreich, 2000; Neugebauer et al., 2001)]. Topographic disunity over the platform gave rise to irregular facies distribution and thickness of carbonate successions of different parts of the platform.
Significant interruptions of carbonate successions are also related to global eustatic oscillations and/or oceanic anoxic events, but they are mainly superimposed on tectonically induced changes of relative sea-level.

Thus before the beginning of the uplift of northern part of the Adriatic Carbonate Platform in the Late Cretaceous and the synchronous onset of flysch sedimentation in the area north and north-eastern of the platform, the whole region was already topographically distinctly heterogeneous. Flysch started to deposit in deeper marine basin with partly inherited bathymetry from former deeper marine domain of Slovenian Basin and drowned Julian Carbonate Platform (Fig. 5). Deeper marine realms with more or less uninterrupted sedimentation had still encircled the carbonate platform from its western and southwestern side (Vlahović et al., 2005) (darker grey area on Fig. 5).

Later tectonic activity which shortened the area and displaced different parts of the region, prevent more accurate interpretation of geotectonic conditions at those time. Namely, except the substantial shortening of the region due to different "thrusting" phases of Alpine orogeney, the area north from the Periadriatic Fault Zone was displaced for at least $100 \mathrm{~km}$ eastward during the Miocene (Ratschbacher et al., 1991; Frisch et al., 1998; Vrabec \& Fodor, 2006), in some estimates up to $500 \mathrm{~km}$ (Haas et al., 1995). It should be noted that western Istria (i.e. Dinaric Foreland on Figure 1) experienced significant counterclockwise rotation most likely between the end of Miocene and the earliest Pliocene (Márton et al., 1995; Márton, 2006).

\section{PALEOKARST}

In the investigated area both surface and subsurface paleokarstic features occur. In places the paleokarstic surface is denoted by surface karst forms like karrens, dolines and depressions of decimetric amplitude (Fig. 6a). Pedogenic features and enlarged root-related channels characterize the upper part of the vadose zone, the epikarst. Vadose channels, shafts and pits penetrate up to a few tens of meters bellow the paleokarstic surface, where they may merge with originally horizontally oriented phreatic cavities. The latter comprise characteristics of caves forming in fresh/brackish water lenses. At least some of them may be defined as flank margin caves (Fig. 6b, 6c). In extensive outcrops, the remains of such caves can be followed as much as few hundreds of meters along strike. In one case a breccia body which was defined as paleokrastic cave related deposit (Otoničar et al., 2003), is so extensive that was used even as mappable unit for Basic geologic map of
Yugoslavia 1:100.000 (see Magaš, 1965). The cavities are usually irregular and elongated in shape, and could be up to few tens of meters long and up few meters high (Fig. 6b). Depending on locality, the phreatic cavities were found in different positions regarding to the paleokrastic surface, the lowest one some 75 meters below it. The cavities had been subsequently partly reshaped and entirely filled with sediments and flowstones in the upper part of the phreatic, epiphreatic and vadose zones (Figs. 6b, 6c). Similarly, the vadose channels and voids are also filled by sediments and flowstones, but they usually differ from these of phreatic cavities in higher content of noncarbonate material, lower $\delta 13 \mathrm{C}$ values of carbonate material and more distinctive pedogenic modification. The denudation had frequently exposed filled paleokarstic subsurface cavities on the paleokarstic surface, where they may be identified only by the remains of their fill (Otoničar 

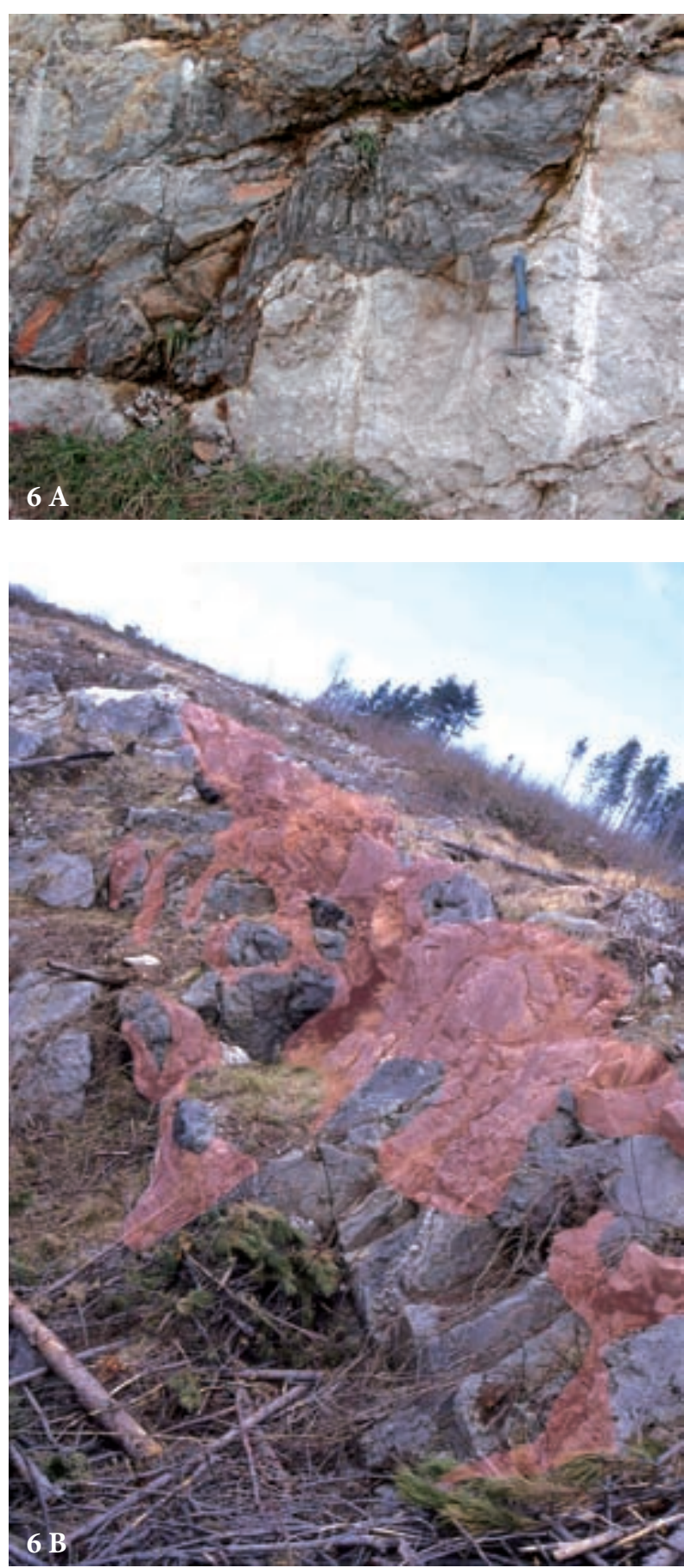

et al., 2003) (Fig. 6c). The internal sediments and flowstones often occur as grains in deposits that cover the paleokarstic surface or fill subsurface paleokarstic cavities of different generations. Paleokarstic surface with its depressions as well as subsurface channels and voids are often covered and filled by bauxite deposits which were locally exploited (Fig. 6d) (Gabrić et al., 1995).

Certain limestone lithofacies of immediate cover of the unconformity are commonly locally confined, sug-
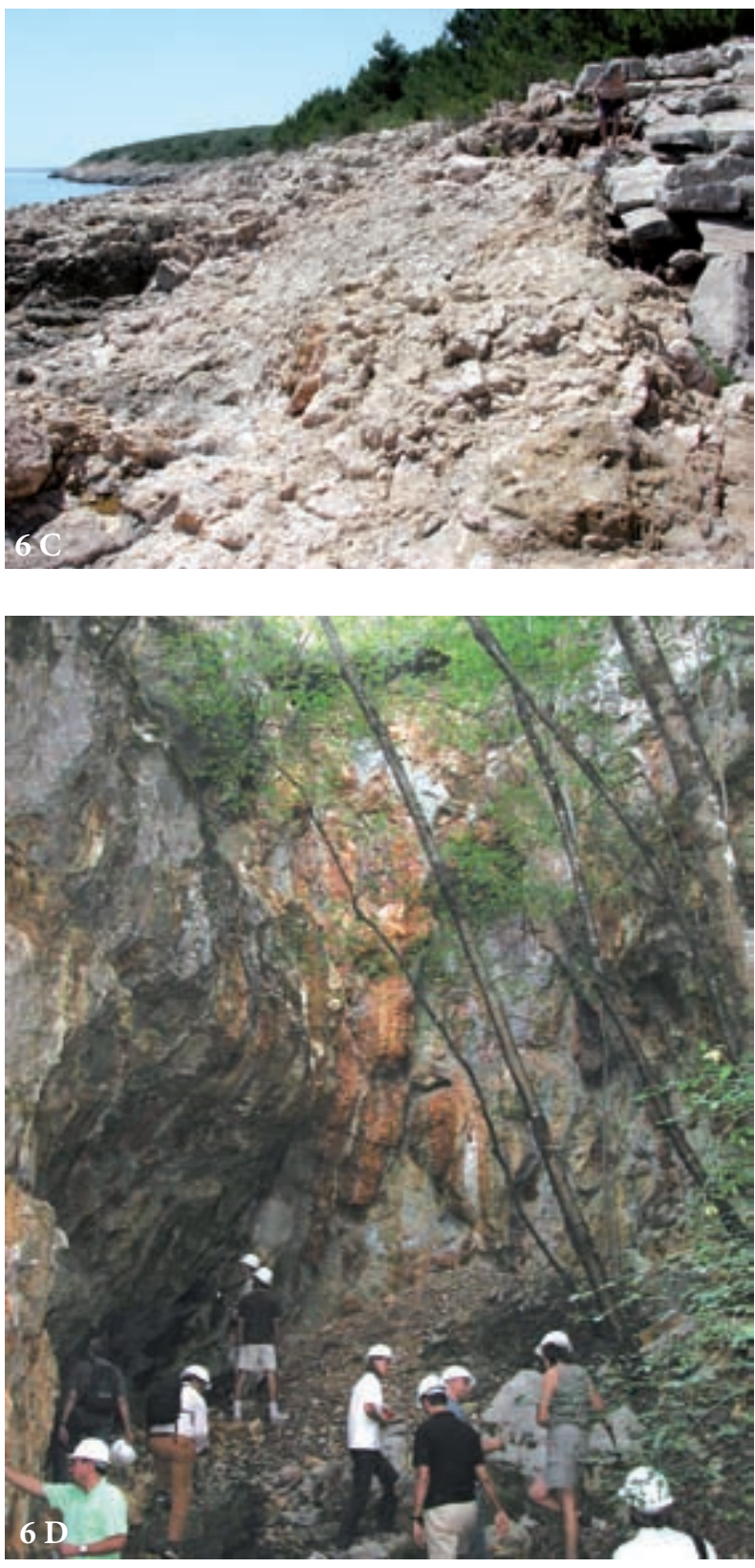

Fig. 6: A) Paleokarstic surface is locally denoted by small scale depressions (motorway road-cut at Kozina village, SW Slovenia). Note colour contrast between Upper Cretaceous shallow marine limestone of the Lipica Formation and dark grey palustrine limestone of the Liburnia Formation. Hammer for scale is about $30 \mathrm{~cm}$ high. B) Horizontally oriented cave of irregular shape largely filled with reddish-stained calcareous mudstone/siltstone (Podgrad, Matarsko Podolje, SW Slovenia). The maximal height of the cave is approximately 4 meters. The cave deposits are artificially marked by reddish transparent colour on the photograph. C) Breccia body represents a part of filled roofless paleokarstic phreatic cave at Koromačno in Istria, NW Croatia. (1,8 $\mathrm{m}$ tall geologist for scale in the upper right corner) D) Excavated paleokarstic cavity (vadose shaft?) originally filled with bauxite (Minjera, Istria, NW Croatia). 
gesting highly irregular topography of the karstic surface before the beginning of transgression. In places it is clear that the incipient transgression involved gradual increase of groundwater table and, eventually, ponds or "blue holes" were formed in karstic depressions (Durn et al., 2003). In the Kozina site (southwestern Slovenia) during the "blue hole" stage of the transgression, a paleokarstic pit was filled by coarse grained breccia with vertebrate remains, mainly dinosaurian and crocodilian bone fragments and teeth (Debeljak et al., 1999, 2002). Generally, the cover sequence (i.e. the Liburnian Formation of Maastrichtian and early Paleogene age) is characterized by restricted, marginal marine and palustrine lithofacies, which frequently show pedogenic modifications.

\section{EVOLUTION OF THE PERIPHERAL BULGE (THE FOREBULGE)}

Besides the research on paleokarst related phenomena, the study of sedimentary successions of the host rock in which the paleokarstic features occur and those that overlie the paleokarstic surface is of crucial importance to understand the uplift of substantial part of the Adriatic Carbonate Platform above the sea-level in the Late Cretaceous and Paleogene. To explain the mechanisms that govern the uplift, regional and global geotectonic and eustatic conditions were taken into consideration, too.

\section{STRATIGRAPHY}

The age of the limestones that immediately underlie the unconformity and the extent of the chronostratigraphic gap in southwestern Slovenia and Istria systematically increase from northeast towards southwest (Figs. 2, 7a, $7 b$ ), while the age of the overlying limestones decrease in this direction (Figs. 2, 7c). In western part of Istria the orientation of the isochrones is slightly different and
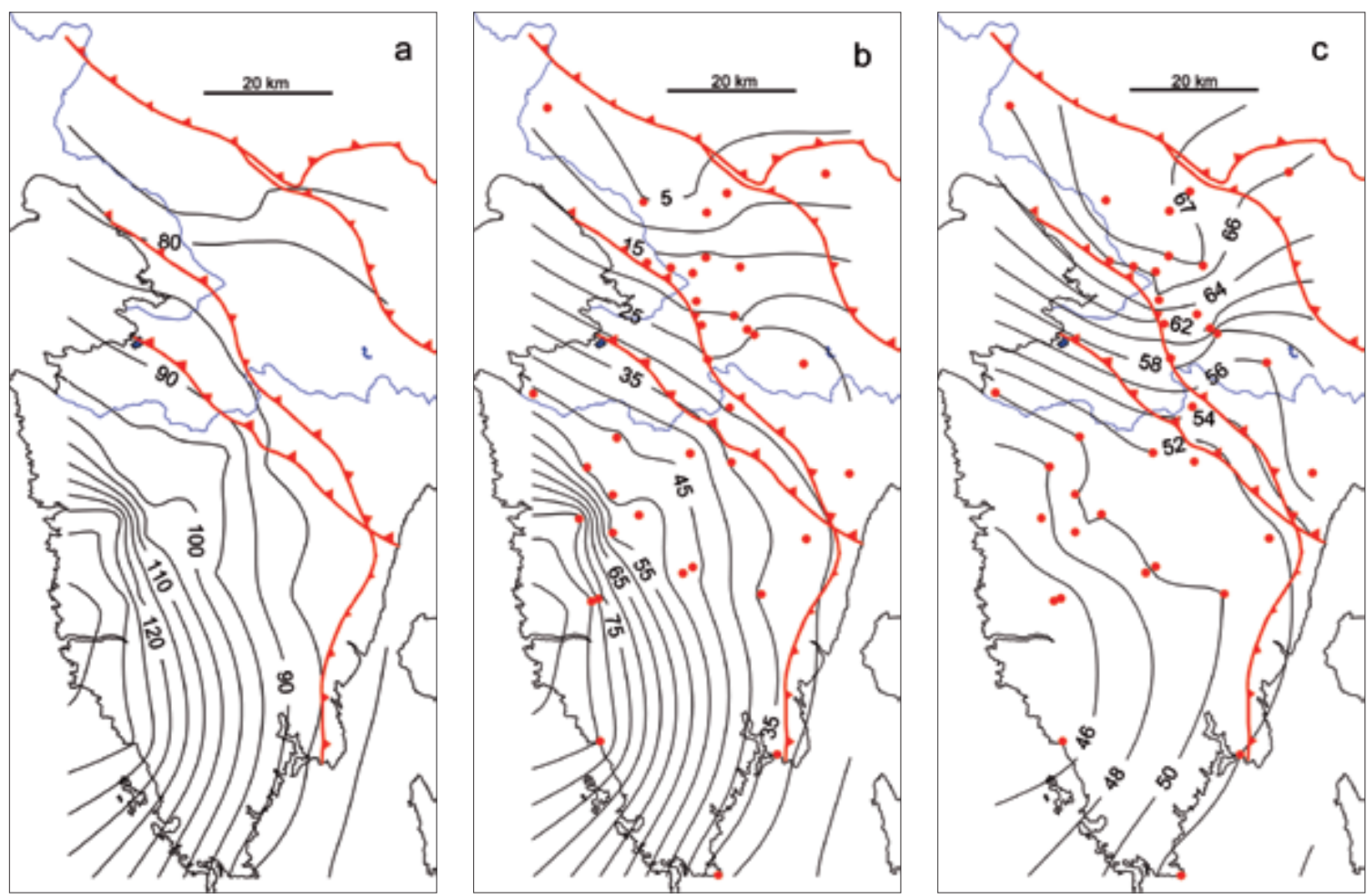

Fig. 7: A) Isochrones of carbonate rocks that immediately underlie the unconformity. B) Isochrones of the extent of the chronostratigraphic gap. C) Isochrones of carbonate rocks that immediately overlie the unconformity. Isochrones in all figures are in Ma. Major structural elements of the area (see Fig. 1) and positions of the geological profiles used in the research (see Fig. 2) are also shown in the figures. 
shows a dome-like topography of the forebulge. The isochrones represent a statistic result acquired by kriging in Surfer programme version 8.00 (๔ Golden Software, Inc.). The data were provided from 36 geological profiles from the karstic regions of southwestern Slovenia, both Slovenian and Croatian part of Istria peninsula and the area between Trieste bay and Italian-Slovenian border in northeastern Italy (Figure 2 and red dots on Figures $7 \mathrm{a}, 7 \mathrm{~b}, 7 \mathrm{c})$.

The youngest rocks below the unconformity belong to mid-Campanian and occur in the central and northeastern part of the Kras (Karst) plateau (the Komen thrust sheet) (Fig. 1) (Jurkovšek et al., 1996) and close to Postojna (the Snežnik thrust sheet) (Fig. 1) (Šribar, 1995; Rižnar, 1997) in southeastern Slovenia, while the oldest one, Valanginian and Hauterivian in age, crop out in the western part of Istria (Matičec et al., 1996) (Figs. 2, 7a).

The beds that cover the unconformity correspond to different ages, litofacies, members and formations. As mentioned afore, the age trend of the immediate cover is opposite to that of the footwall. In this case the oldest rocks occur in southwestern Slovenia and belong to the youngest stage of the Late Cretaceous - the Maastrichtian. Towards southwest, progressively younger deposits onlap the paleokarstic surface (Figs. 2, 7c). However, the youngest strata that onlap the unconformity don't fit exactly with the oldest one immediately below it. With regard to described situation, the chronostratigraphic gap increases considerably from few $\mathrm{Ma}$ on the Kras plateau (southwestern Slovenia) to more than $80 \mathrm{Ma}$ in western Istria (Figs. 2, 7b).

The lithofacies of the lower part of the cover sequence (The Liburnian formation) frequently show features typical of subaerial exposure surfaces, including calcrete, pseudomicrokarst, brecciated horizons and karstic surfaces. Locally, the lowermost subaerial exposure surface of the Liburnija Formation, which shows karstic topography of decimetric amplitude, and the main paleokarstic surface form a composite unconformity. Sporadically, thin coal beds and seams occur in the lower part of the sequence. Although the stratigraphy of the Kras Group, "Transitional Beds" and Flysch (Fig. 3) shows overall deepening of the basin, prominent subaerial exposure surfaces also occur in carbonate successions of Trstelj Beds and Alveolina-Nummulites Limestone (Košir \& Otoničar, 1997; Košir, 2003). Much thicker successions of paralic sediments with more frequent unconformities and marsh related sediments occur in southwestern Slovenia and northeastern Istria in comparison with other parts of Istria, yet local variation can be significant (Figs. $2,8)$. In western Istria, where the chronostratigraphic gap is the most extensive, the foraminiferal limestones frequently lie directly on the paleokarstic surface (Matičec at al., 1996). The thickness of the Kras Group generally decreases from northeast toward southwest, although also in this case significant deviations may occur (Figs. $2,8)$.

The point where the unconformity pinch-out towards the foreland basin occurs somewhere between the northeastern part of the Kras plateau on the Komen Thrust Sheet and some $10 \mathrm{~km}$ (approximately $25 \mathrm{~km}$ in original position - see Placer, 1999) distant Mt. Nanos on the Hrušica nappe (Fig. 1). From this point on towards the foreland basin, the uplift of the forebulge didn't take place because the area was so close to the orogene that experienced only a subsidence. Here, the sedimentary succession of the Adriatic Carbonate Platform gradually passes into progressively deeper-marine carbonate succession of synorogenic carbonate platform. Namely, on the Mt. Nanos at Campanian-Maastrichtian boundary, the deepening of the shallow marine carbonate platform without any evidence of preceding emersion is documented (Šribar, 1995).

Further towards the northeast, in the Julian Alps (the eastern part of the Southern Calcareous Alps) and in the most northern part of recent Dinaric mountain belt in western Slovenia and northeastern Italy (the Trnovo Nappe), the turbiditic siliciclastic sediments (flysch) started to deposit in Campanian and Maastrichtian over the rocks of different lithology, age and origin (Pavšič, 1994). Flysch often overlies deeper marine pelagic marls of "scaglia" type and alodapic carbonates, which were receiving the material from Adriatic Carbonate Platform. It is important to note that in this part of western Slovenia deep-marine basin existed before flysch or above mentioned deeper marine pelagic marls started to deposit. However, the oldest pelagic marls (pre-flysch deposits) which overlie the Upper Cretaceous shallow marine carbonates of the northeastern margin of the Adriatic Carbonate Platform also belong to Maastrichtian. Similar as I stated for chronostratigraphic gap, the pelagic marls and flysch deposits are also diachronous over the area. From northeast toward southwest, successively younger strata onlap the pre-foreland basin deposits (Fig. 4).

The successions of pelagic marls and especially siliciclastic flysch were periodically interrupted by deposition of calcarenitic and calcruditic beds/megabeds, locally even of olistostrome character. Those beds were supplied by turbiditic currents from the fault-related escarpments of distorted and seismically active marginal areas of former Adriatic Carbonate Platform (Skaberne, 1987; Tunis \& Venturini, 1987) and later also from outer parts of synorogenic carbonate platforms (distally steepened ramps?) (Fig. 9).

The synorogenic carbonate and siliciclastic deposits of other parts of External Dinarides (e.g. Dalmatia) are 


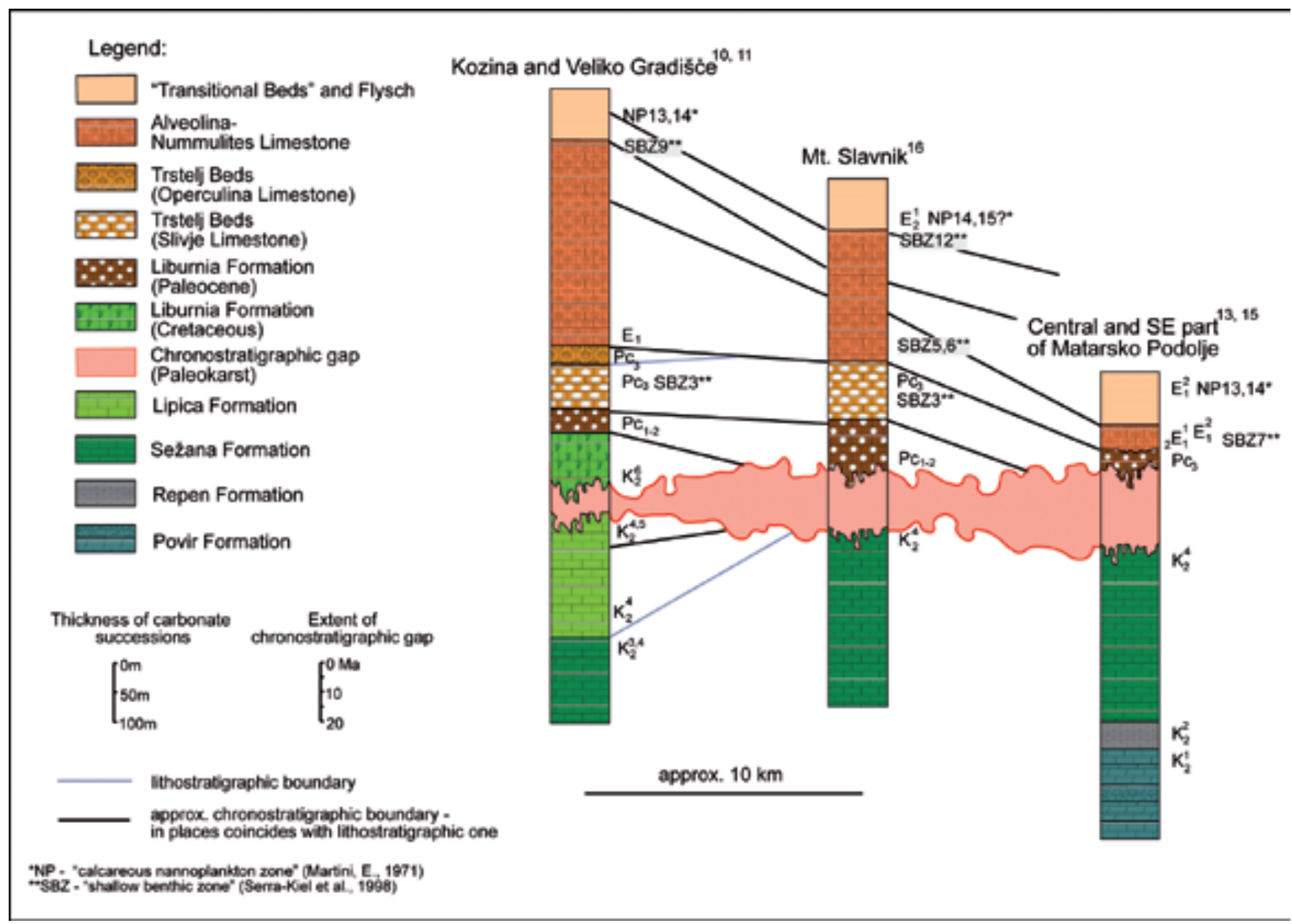

Fig. 8: Lithostratigraphic columns for three adjacent sites in Matarsko Podolje and Mt. Slavnik (SW Slovenia). Note significant variations in thickness of lithostratigraphic units and in time span of stratigraphic gap.

younger than these described here. They started to deposit not before Eocene (Marjanac \& Ćosović, 2000) and probably represent deposits of different foreland system or at least of different segment of the one described here.

\section{DISCUSSION}

Systematic trends expressed by isochrones showing the age of the carbonate rocks that immediately under- and overlie the paleokarstic surface (Figs. 7a, 7c), and consequently, the extent of the chronostratigraphic gap (Fig. 7b), can be explained mainly by the evolution and topography of peripheral foreland bulge (the forebulge) (Fig. 9).

When the foreland continental lithospheric plate is vertically loaded by the fold and thrust belt, it responds with flexure. In front of the evolving orogen an asymmetric foreland basin is formed; the deepest part of the basin (the foredeep) is located adjacent to the orogenic wedge (Fig. 9). Because of the isostatic rebound on vertical loading of the lithosphere, the opposite side of the basin (opposite to the orogenic wedge) is instantaneously upwarped and the bulge with subtle relief is formed, the peripheral bulge or the forebulge. The bulge is especially well expressed in early, flysch stage of the foreland basin evolution (Crampton \& Allen, 1995). While the wavelength of the deflection is approximately the same for both, foreland basin and peripheral bulge, the amplitude of the basin subsidence is typically much greater as the uplift of the bulge (Crampton \& Allen, 1995; Miall, 1995). If the conditions are suitable, synorogenic carbonate platforms with distinctive ramp topography may colonise the gentle slope of the forebulge toward the foredeep (Dorobek, 1995).

Significantly, as the whole complex of the orogenic wedge advances forelandward, the flexural profile produced by the orogenic wedge advances with it. Topography of the forebulge is controlled by numerous factors, among which the rigidity of the foreland lithospheric plate and the rate of emplacement of the load are the most important (Allen \& Allen, 1992; Dorobek, 1995; Miall, 1995). An expected maximal height of the forebulge above the sea level (if the foreland plate is at or close to sea-level prior to flexural loading) would be in the range of up to a few tens to few hundreds meters (Crampton \& 


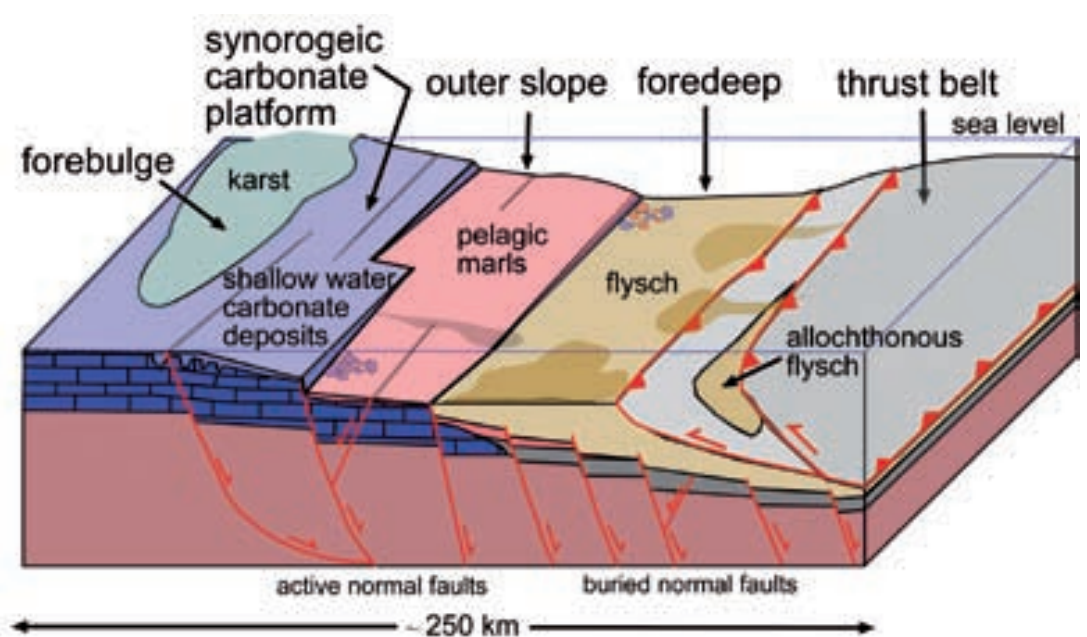

Fig. 9: Schematic block diagram of foreland basin complex showing the position of the orogenic wedge, foredeep and forebulge with distribution of macrofacies belts before plate convergence ended (modified from Bradley \& Kidd, 1991).

Allen, 1995; Miall, 1995). According to topography of the forebulge, the rate of erosion (see White, 2000) and the style of migration of the orogenic wedge, the area of maximal denudation should occur in the central part of the region, which is over-passed by the bulge (Crampton \& Allen, 1995). In addition, non-flexural deformations (e.g. reactivation of pre-existing heterogeneities, enhanced deflections because of horizontal in-plane stresses...) and inherited topography may significantly influence the evolution and topography of the forebulge (Allen \& Allen, 1992; Dorobek, 1995; Miall, 1995; Crampton \& Allen, 1995).

On Mt. Nanos (Hrušica Nappe; Fig. 1) shallow water rudist limestone of the Adriatic Carbonate Platform gradually passes over limestone with orbitoidiform larger foraminifera into pelagic marls without any emersion at the base of the deepening sequence - the erosional gap reduces to conformity. The age span of this transition falls within a period of the shortest documented chronostratigraphic gap between the northeastern part of former Adriatic Carbonate Platform and the overlying synogenic carbonate platform (Fig. 2), which extends from midCampanian to Late Maastrichtian. Maastrichtian in age are also the oldest pelagic marls which in places directly overlie the Upper Cretaceous shallow water carbonates of former northeastern margin of the Adriatic Carbonate Platform. Although the oldest turbiditic siliciclastic flysch was deposited in a basin with inherited deeper marine bathymetry (former Slovenian Basin) its Campanian and Maastrichtian age could be correlated with other incipient foreland related deposits and phenomena. With regard to these criteria and trends of unconformity related isochrones elsewhere (Figs. 2, 7a, 7b, 7c), I suggest that northern part of the Adriatic Carbonate Platform had thrived more or less prosperously till the end of Campanian, when an initial uplift of the forebulge occurred. The carbonate sediments that had originally been deposited till that time, and are now missing in carbonate successions immediately below the unconformity, had been erased during the paleokarstic period by the karstic denudation processes.

According to topography of the forebulge and advancing nature of the foreland geodynamic complex as a whole, the most extensive denudation is expected in the central area over which the forebulge migrates. The western part of Istria, where the chronostratigraphic gap is the largest and the beds immediately below the unconformity are the oldest (Fifs. 2, 7a, 7b), most probably corresponds to this zone. However, in an ideal conceptual/mathematical model of the forebulge unconformity, the amount of erosion should remain more or less constant over vast area in the central part of the region over-passed by the bulge, and decreases on its distal slope towards back-bulge basin (Crampton \& Allen, 1995). Instead, in western Istria the isochrones of the beds underlying the unconformity show distinctive condensation compared to situation in northeastern Istria and southwestern Slovenia (Fig. 7a). I suggest that this is not the result of rapid increase of the amount of footwall eroded but rather of denudation of primarily much thinner Cretaceous carbonate successions in western Istria. Namely, in this part of Istria the carbonate successions are relatively thin (Matičec et al., 1996), partly because of repeating emersions throughout the Cretaceous (Velić et al., 1989) and partly because of reduced accommodation space of Cretaceous shallow marine environments. Evidence of considerable Late Jurassic and Cretaceous land areas in the vicinity of western Istria (probably offshore form its recent west coast), came also from dinosaur record (footprints and bones) (Della Vecchia et al., 2000; Mauko \& Florjančič, 2003; Mezga et al., 2003) and distribution of sedimentary facies of the adjacent peritidal to deeper marine environments of intraplatform basins (Tišljar et al., 1995; 1998). Why was the area of western Istria beeing preferentially uplifted during the Cretaceous is still questionable, but the reasons for deflections should be searched at adjacent plate boundaries where their reorganisation and different collision-related events and processes (see Faupl \& Wagreich, 2000; Neugebauer et al., 2001) produced hori- 
zontal in-plane stresses that may be transmitted many hundreds of kilometers inboard of actual collision (Zeigler et al., 1995).

It is also possible that the central zone of the forebulge and the slope towards back-bulge basin in their final position occurred offshore of recent Istrian west coast. However, we should be aware that the Late Cretaceous Adriatic Carbonate Platform was surrounded from the western side by deeper marine interplatform basins (Vlahović et al., 2005) what might considerably affected the appearance of the forebulge and the back-bulge area.

Although the "abnormal thickness" of denuded stratigraphy in western Istria is mainly the result of previous sedimentary history, some uncertainties may also arise from differential uplift/subsidence of certain parts of the forebulge. Evidence for differential subsidence along reactivated ancient tectonic structures is for example well documented in carbonate successions of the Kras Group, where the thickness of chrono- and lithostratigraphic units may vary considerably over short distances (Figs. 2, 8).

In conclusion I suggest that the denudation exposed the oldest carbonate rocks in the western Istria partly because of specific evolution (migration) and topography of the forebulge and partly because of primarily thinner carbonate successions in this part of Istria compared to more northeastern parts of the investigated area.

The rate of transgression over the paleokarstic surface is expressed by the isochrones of the strata that onlap the unconformity (Fig. 7c). While the large scale diachronism of the onlapping strata shown in Figure $7 \mathrm{c}$ is the result of specific large-scale topography and migration of the forebulge as a whole, local smaller scale spatial differences in the onlap pattern (not observable in Figure $7 c$ ) are due to shorter oscillations of relative-sea level and deposition over topographically irregular paleokarstic surface (e.g. dolines, shafts... - a "blue hole phase" of the transgression). The pattern of the isochrones shown in Figure $7 \mathrm{c}$ suggests that the transgression during its earlier stages (southwestern Slovenia and northeastern Istria) was slower compared to its later stages (western Istria). Although subsequent tectonic deformations, such as tectonic shortening, faulting and rotation, substantially affected the area, the rate of the onlap in southwestern Slovenia and northeastern Istria is estimated to about 2-3 $\mathrm{km} / \mathrm{Ma}$ while in southwestern Istria to about $4-5 \mathrm{~km} / \mathrm{Ma}$. We should be aware that some apparent anomalies, especially at terminations of the isochrones may be the result not only of later tectonic deformations of the area but also of limited number of data points which are not uniformly distributed, spatially confined area of the investigation along the strike of the forebulge and defectiveness of statistic method (kriging) used. Slightly different orienta- tion of the isochrones in western part of Istria compared to those in southwestern Slovenia and northeastern Istria (Figs. 7a, 7b, 7c) may also be the result of different sydepositional or synorogenic orientation of the prevailing stresses (see Marinčić \& Matičec, 1991; Matičec et al., 1996) during the Cretaceous and Paleogene and later counterclockwise rotation of the area (see Márton et al., 1995 amd Márton, 2006). In spite of all that, the reasons for different stratigraphic pinch-out rate are many sided and may arise from differential rheologic and structural characteristics of the foreland plate itself, events at collision zone and adjacent plate boundaries, sublithospheric processes and external reasons like eustatic sea-level oscillations and climate changes. In our case it is difficult to determine the exact reason for the increasing rate of the onlap in Lower Eocene, not only because different processes may lead to the same result, but also because they can act simultaneously.

Long term sea-level fall (i.e. second-order cycle of Haq et al., 1987) may for example slow-down the onlap rate and vice-versa long term sea-level rise may increase the onlap rate. If we observe the eustatic curve for the Cretaceous and Paleogene (Haq et al., 1988) we can notice that the rate of the onlap is in relatively good agreement with mid-Campanian to Late Paleocene second-order fall and Early Eocene rise of the sea-level. However, the foreland basin should progressively widen and pinchout migration rate would increase also if, for example, the orogenic wedge loaded a progressively stronger elastic lithosphere (Allen \& Allen, 1992).

Although not all local variations of relative sea-level oscillations and so the onlap rate could be identified from isochrones in the Figure 7c, they could be observed in the field. Namely, the subaerial exposure surfaces that periodically interrupt the carbonate sedimentation of the Liburnia Formation reflect relative sea-level falls. Short term falls (i.e. third-order cycles of Haq et al., 1987), which were documented in Late Maastrichtian, Late Paleocene and Early Eocene (Haq et al., 1988), could cause these unconformities.

On the other hand, a few other processes may influence the rate of the onlap. The forebulge should increase in height and migrate toward the orogenic wedge over time if the foreland lithosphere behaves viscoelastically even when the load is unchanging (Tankard, 1986). However, estimations for time constants of the viscous relaxation of stresses are longer than actual amount of time available for the forebulge migration (Allen \& Allen, 1992; Dorobek, 1995). Variation in onlap rate may reflect also changes in sediment supply, or within the orogenic wedge, such as the formation of a new thrust complex (Crampton \& Allen, 1995) or transition from passive to active thrusting phase. An increase in com- 
pressive in-plane stress produced during convergence also might enhance uplift of the forebulge and causing shoreline regression along its flank (Allen \& Allen, 1992; Dorobek, 1995).

Evidence of short term sea-level oscillations could also be recognized from the specific evolution of the paleokarst, especially phreatic caves. If the majority of lenticular caves with irregular walls and discrete horizons of spongework or swisse-cheese like vugs on young carbonate islands originated at/in fresh/brackish water lenses (see Mylroie \& Carew, 1995), then in our case the major part of the cavities had been emplaced in the vadose zone prior to submergence and burial. Namely, the caves are frequently completely filled with deposits originated in vadose zone, like flowstone and bauxite, or they had been opened to the paleokarstic surface by complete denudation of the roof (i.e. roofless caves of Mihevc, 2001). If the water-level is stagnant and the forebulge migrates, than in the conceptual sense only those phreatic cavities developed below that forebulge flank that facing towards back-bulge basin should be uplifted in the vadose zone before subsidence. On the contrary, phreatic caves developed below the flank facing the foreland basin and the advancing orogenic wedge should suffer nothing but subsidence and subsequent burial. Theoretically it is possible that because of the advancing character of the forebulge, caves formed in different sides of the forebulge may occur in the same karstic profile. Phreatic cavities developed below the flank facing towards the back-bulge region should be uplifted and modified in the vadose zone. Subsequently, after the crest of the forebulge migrates over the back-bulge flank, the "back-bulge" phreatic caves should re-immerge into phreatic zone, but this time below the flank facing towards the foreland basin. It is important to note that frequently observed multiphase modifications of originally phreatic caves could also be the result of the same causes of relative sea-level oscillations that govern the onlap character of the beds that overlie the unconformity (e.g. relaxation of the viscoelastic bulge, formation of a new thrust complex, increase of horizontal in-plane stress, eustatic sea-level fall...).

The carbonate platform was subsequently re-established and finally buried by prograding deeper-marine clastics (pelagic marls and flysch) of the migrating foreland basin (Fig. 9). As it has been already discussed, shallow-water carbonate successions that cover the unconformity may yield a considerable amount of information about relative sea-level oscillations and geodynamics of the forebulge.

Paralic/shallow-marine successions with frequent unconformities and palustrine deposits of the Liburnia Formation (Fig. 3) are usually much thicker in southwestern Slovenia and northeastern Istria than in central and western Istria (Fig. 2). There the paleokarstic surface is frequently directly overlain by foraminiferal limestones (Matičec at al., 1996). The general trend of thickness and the rate of transition from shallow to deep marine environments (drowning) (Fig. 2) are in good agreement with the rate of the onlap (Fig. 7c) and should be the result of the same processes that caused the differentiations in the onlap pattern. I suggest that the anomalies in thickness and facies distribution that could be in places quite distinctive may arise from reactivation of inherited geological structures due to the approaching orogenic wedge.

It has been discussed already, that the orogenic phases could be recognised from structural and stratigraphic data even in areas that are located at some distance from the source of tectonic activity at plate boundaries (e.g. collision and orogenesis). Because of later tectonic deformations it is sometimes difficult to define the exact tectonic phase which affects the area and the actual source of tectonic activity.

In our case, the structural and stratigraphic data indicate the evolution of migrating synorogenic foreland basin complex, which should be the result of collision processes and the evolution of the advancing orogenic wedge (see e.g. Allen \& Allen, 1992; Crampton \& Allen, 1995; Miall, 1995). At first sight it seems normal to link the foreland complex to tectonic phase that generated structures by mainly NE-SW compression (mesoalpine phase of some authors; see Doglioni \& Bosellini, 1987) and gave rise to Dinaric mountain belt during its final stages. However, the Dinaric orogenic belt of which final uplift occurred during the Oligocene-Miocene (Vlahović et al., 2005) is supposed to be the result of collision between Tisia and Adria microplates with onset of collision during the Eocene (Pamić et al., 1998; Pamić, 2002), what is also the age of the oldest synorogenic deposits of the "coastal" part of the External Dinarides (Marjanac \& Cosović, 2000). On the contrary, although the nappe structures of western Slovenia and Late Cretaceous - Paleogene compressional deformations of northeastern Italy indicate NE-SW or ENE-WSW compression, and so "Dinaric" orientation of prevailing regional stress, the oldest foreland basin deposits in these regions are much older than those of other parts of the External Dinarides and belong to the latest stages of Late Cretaceous (Pavšič, 1994; Doglioni, 1987; Doglioni \& Bosellini, 1987). As it is shown on Figure 4 the age distribution of flysch deposits indicates the advancing nature of foreland basin from northeast towards southwest what is in accordance with "Dinaric" orientation of the prevailing regional stress. While south of Zagreb-Zemplen fault line, the remnants of oceanic lithosphere (i.e. ophiolite melange) as well as subduction and collision related rocks of Internal Dinarides (i.e. the Sava-Vardar zone by Pamić et 
al, 1998), which could be linked to closing processes of the Vardar Ocean and collision between Tisia and Adria (Pamić, 2000) are widespread, north of Zagreb-Zemplen line no such rock has been found so far. It seems possible that in central Slovenia, in prolongation of the Sava-Vardar zone, such rocks have been buried by Tertiary sediments and Southern Alpine nappes. In addition, on the NNE side the nappe structure of Western Slovenia was cut from its "root zone" by Periadriatic fault. The "root zone" should be displaced for at least $100 \mathrm{~km}$ eastward during the Miocene (Ratschbacher et al., 1991; Frisch et al., 1998; Vrabec \& Fodor, 2006).

Although, the structural and sedimentary features of eoalpine tectonic phase which culminated in midCretaceous orogeny in the Austroalpine domain (Faupl \& Wagreich, 2000) and also affected the central and western part of the Italian Southern Alps (Doglioni, 1987; Doglioni \& Bosellini, 1987) mostly pre-date the foreland related features and sediments described here, it should be noted that in Istria Tertiary tectonic cycle (from Eocene on) display distinctively different orientation of the prevailing stress than Mesozoic one (Marinčić \& Matičec, 1991; Matičec et al., 1996).

In conclusion, the foreland basin complex in western Slovenia and Istria was probably formed during mesoalpine ("Dinaric") tectonic phase, although some influences of eoalpine tectonic phase could be important in earlier stages of its evolution. The time discrepancy and also the exact orientation of prevailing regional stress are probably the result of oblique collision between Adria and Tisia microplates (and/or Austroalpine terrane?) and/or segmentation of the foreland plate (see Ricci-Lucchi, 1986; Allen \& Allen, 1992).

Oligocene to recent tectonic events especially in Dinarides and Apennines, and conter-clockwise rotation of Adria importantly modified the area formerly occupied by the forebulge, but this is already beyond the scope of this paper.

\section{CONCLUSIONS}

In spite of all structural and depositional heterogeneities and subsequent tectonic deformation of the area the paleokarstic unconformity marked by distinctive surface and subsurface paleokarstic features exhibits characteristics typical of a forebulge unconformity:

1) From northeast towards southwest the unconformity cuts progressively older units which are onlapped by progressively younger shallow water carbonates; the chronostratigraphic gap progressively increases.

2) Deepening upward sequences of synorogenic ramp-like carbonate systems overlie the unconformity. In marginal parts of the former Adriatic Carbonate Platform towards the foreland basin, a deepening upward sequence is documented also without intermediate unconformity - here the sequence is conformable because the orogenic wedge was so close that the area experienced only subsidence and forbulge uplift had no taken place.

3) The foreland basin with siliciclastic turbiditic flysch deposits was developing synchronously with the forebulge and synorogenic carbonate platforms. It was also advancing synchronously in the same direction as they were forebulge and synorogenic carbonate platforms. The stratigraphy overlying the unconformity (i.e. underfilled trinity) representing subsidence in underfilled peripheral foreland basin.

4) Evidence of contemporary seismic activity arises from periodic carbonate resediments (megabeds, olistostromes) find in siliciclastic flysch successions.
They were supplied by turbiditic currents from the fault related escarpments of the forebulge slope (reactivated ancient faults). Besides flexural upwarping because of the isostatic rebound on vertical loading of the foreland lithosphere, other smaller scale flexural and non-flexural deformations significantly influenced the evolution and appearance of the forebulge (incuding its diagenesis and karstification), lithofacies distribution and thickness of the carbonate successions above the unconformity. At least some influence of eustatic sea-level oscillations cannot be excluded.

5) The subaerially exposed area and the facies belts of progressive forelandward advancing shallowmarine, pelagic, and turbiditic depositional environments ahead of the orogenic front are roughly parallel to the Dinaric mountain chain. However, the Dinaric foreland-related system supposedly began to evolve during the Eocene when Tisia and Adria microplates began to collide what is much later comparing to Late Cretaceous onset of foreland basin evolution and forebulge uplift in western Slovenia and Istria. In Istria the orientation of the prevailing regional stress during Cretaceous tectonic cycle differs significantly from Eocene one. I suggest that the foreland basin complex in western Slovenia and Istria was probably formed during mesoalpine ("Dinaric") tectonic phase, due to oblique collision of Adria and Tisia microplates (and/or Austroalpine terrane?) and segmentation of the foreland plate. 


\section{ACKNOWLEDGMENTS}

Most of this work was performed as part of doctoral dissertation at University of Ljubljana. I am grateful to David
Culver for English correction of an earlier version of the manuscript and Adrijan Košir for constructive reviews.

\section{REFERENCES}

Allen, P.A. \& Allen, J.R., 1992: Basin analysis - principles \& applications.- Blackwell science, p. 451, London.

Biondić, B., Braun, K., Vlahović, I., Mlinar, Ž., Andrić, M., Balen, I., Pollak, D., Fuček, L., Oštrić, N., Prtoljan, B., Šaban, B., Blagus, Z., Dukarić, F., Buljan, R. \& Biondić, R., 1995: Inženjerskogeološki model željezničkog tunela Ćićarija.- In: I. Vlahovič, I. Velić \& M. Šparica (Eds.), 1. hrvatski geološki kongres: Zbornik radova, Opatija, 18.-21. oktober 1995. Institut za geološka istraživanja i Hrvatsko geološko društvo, 81-87, Zagreb.

Bosellini, A., 1989: Dynamics of Tethyan carbonate platforms.- In: P.D. Crevello, Wilson, J.L., Sarg, J.F. \& Read, J.F. (Eds.), Controls on carbonate platforms and basin development. Society of Economic Paleontologists and Mineralogists, 3-13, Tulsa.

Brazzatti, T., Caffau, M., Cozzi, A., Cucchi, F., Drobne, K. \& Pugliese, N., 1996: Padriciano section (Karst of Trieste, Italy).- In: K. Drobne, Š. Goričan \& B. Kotnik. (Eds.), The role of impact processes in the geological and biological evolution of planet Earth: international workshop, Postojna, Slovenia, September $27^{\text {th }}$ - October $2^{\text {nd }} 1996$. Znanstvenoraziskovalni center SAZU, 189-198, Ljubljana.

Bradley, D. C. \& Kidd, W. S. F., 1991: Flexeal extension of the upper continental crust in collisional foredewps.- Geological Society of America Bulletin, 103, 1416 - 1438.

Buser, S. \& Lukacs, E., 1972: Geologija boksitov v okolici Karojbe v Istri.- Zbornik 7. kongresa geologa Jugoslavije, Zagreb, 1972., 13-30, Zagreb.

Buser, S. \& Lukacs, E., 1979: Bauxite in Slowenien.- Ann. Inst. Geol. Hungarici, 54, 3, 209-220.

Buser, S. \& Radoičić, R., 1987: Dazikladacejske alge u srednjopaleocenskim miliolidskim krečnjacima na Krasu u Sloveniji $=$ Dasycladacean algae in Middle Paleocene miliolid limestones in Kras in Slovenia.Geologija, 28/29 (1985/1986), 69-91.

Buser, S., 1986: Osnovna geološka karta SFRJ. List Tolmin in Videm (Udine) [Kartografsko gradivo]. 1:100.000. Zvezni geološki zavod, Beograd.
Buser, S., 1989: Development of the Dinaric and the Julian Carbonate Platforms and of the intermediate Slovenian Basin (NW Yugoslavia).- In: G. Battista Carulli, F. Cucchi in C. Pirini Radrizzani (Eds.), Evolution of the karstic carbonate platform: Relation with other periadriatic carbonate platforms, Trieste, 1987. Mem. Soc. Geol. It., 40, 313-320, Trieste.

Buser, S., Grad, K. \& Pleničar, M. 1967: Osnovna geološka karta SFRJ. List Postojna [Kartografsko gradivo]. 1:100.000. Zvezni geološki zavod, Beograd.

Buser, S., Grad, K. \& Pleničar, M. 1968: Osnovna geološka karta SFRJ. List Gorica [Kartografsko gradivo]. 1:100.000. Zvezni geološki zavod, Beograd.

Cousin, M., 1981: Les rapports Alpes-Dinarides.- Les confins de l'Italie et de la Yougoslavie. Soc. Gol. Nord, 5, 1-521.

Crampton, S. L. \& Allen, P. A., 1995: Recognition of forebulge unconformities associated with early stage foreland basin development: example from the North Alpine Foreland Basin.- AAPG Bulletin, 79, 10, 1495 - 1514.

Debeljak, I., Košir, A. \& Otoničar, B., 1999: A preliminary note on dinosaurs and non-dinosaurian reptiles from the Upper Cretaceous carbonate platform succesion at Kozina (SW Slovenia) $=$ Preliminarno obvestilo o dinozavrih in drugih reptilih iz zaporedja zgornjekrednih platformnih karbonatov pri Kozini (JZ Slovenija).- Razpr. - Slov. akad. znan. umet., Razr. naravosl. vede, 40, 3-25.

Debeljak, I., Košir, A., Buffetaut, E. \& Otoničar, B., 2002: The Late Cretaceous dinosaurs and crocodiles of Kozina (SW Slovenia): a preliminary study.- Mem. Soc. Geol. Ital., 57, 193-201.

Della Vecchia, F., Tarlao, A., Tentor, M., Tunis, G. \& Venturini, S., 2000: First record of Hauterivian dinosaur footprints in southern Istria (Croatia).- In: I. Vlahović \& R. Biondić (Eds.), 2. hrvatski geološki kongres: Zbornik radova, Cavtat-Dubrovnik, 17-20. maj 2000. Institut za geološka istraživanja, 143-149, Zagreb. 
Delvalle, D. \& Buser, S., 1990: Macrofacies analysis of limestones from the Upper Cretaceous to the Lower Eocene of SW Slovenia (Yugoslavia).- Geologija, 31 (1988/1989), 351 - 394.

Doglioni, C \& Bosellini A., 1987: Eoalpine and Mesoalpine tectonics in the Southern Alps. Geologische Rundschau, 76, 3, 735-754.

Doglioni, C., 1987: Tectonics of the Dolomites (Southern Alps, Northern Italy).- Journal of structural geology, 9, 2,181-193.

Dorobek, S.L., 1995: Synorogenic carbonate platforms and reefs in foreland basins: controls on stratigraphic evolution and platform/reef morphology.- In: S.L. Dorobek \& G.M. Ross (Eds.), Stratigraphic evolution of foreland basins: Special publication No. 52 . SEPM, 127-147. Tulsa

Drobne, K. \& Pavlovec, R., 1979: Excursion K: Golež paleocene, ilerdian, cuisian.- In: K. Drobne (Ed.), Geological development in Slovenia and Croatia: guidebook, $16^{\text {th }}$ european micropalaentological colloquium, Zagreb - Bled, 8.-16. september 1979. Slovensko geološko društvo in Hrvaško geološko društvo, 217-223, Ljubljana.

Drobne, K., 1977: Alveolines paleogenes de la Slovenie et de l'Istrie.- Mem. suisses de Paleont., 99, p. 174.

Drobne, K., 1979: Paleocene and Eocene beds in Slovenia and Istria.- In: K. Drobne (Ed.), Geological development in Slovenia and Croatia: guidebook, $16^{\text {th }}$ european micropalaentological colloquium, Zagreb - Bled, 8.-16. september 1979. Slovensko geološko društvo in Hrvaško geološko društvo, 49-64, Ljubljana

Drobne, K., 1981: Značilne foraminifere in njih združbe v podlagi danijskih plasti.- Simpozij o problemih danija v Jugoslaviji: Zbornik referatov, 2, 85-97, Ljubljana.

Drobne, K., Ogorelec, B., Dolenec, T., Marton, E. \& Palinkaš, L., 1996: Biota and abiota at the K/T boundary in the Dolenja vas sections, Slovenia.- In: K. Drobne, Š. Goričan \& B. Kotnik. (Eds.), The role of impact processes in the geological and biological evolution of planet Earth: international workshop, Postojna, Slovenia, September $27^{\text {th }}-$ October $2^{\text {nd }}$ 1996. Znanstvenoraziskovalni center SAZU, 163181, Ljubljana.

Drobne, K., Ogorelec, B., Pleničar, M., Zucchi-Stolfa, M. L. \& Turnšek, D., 1988: Maastrichtian, Danian and Thanetian Beds in Dolenja vas (NW Dinarides, Yugoslavia): mikrofacies, foraminifers, rudists and corals.- Razpr. Slov. akad. znan. umet., Razr. naravosl. vede, 29, 147-224.
Drobne, K., Turnšek, D., Cimerman, F., Knez, M. \& Ogorelec, B., 1991: Introduction to the Paleogene SW Slovenia and Istria.- IGCP project 286 - Early Paleogene bentos: field-trip guidebook, p. 85, Ljubljana.

Durn, G., Ottner, F., Tišljar, J., Mindszenty, A. \& Barudžija, U., 2003: Regional subaerial unconformities in shallow-marine carbonate sequences of Istria: sedimentology, mineralogy, geochemistry and micromorphology of associated bauxites, palaeosols and pedo-sedimentary complexes.- In: I. Vlahović \& J. Tišljar (Eds.), 22 ${ }^{\text {nd }}$ IAS Meeting of Sedimentology: field trip guidebook, Opatija, 2003. Institute of geology, 209-254, Zagreb.

Faupl, P. \& Wagreich, M., 2000: Late Jurassic to Eocene palaeogeography and geodynamic evolution of the Eastern Alps.- Mitt. Österr. Geol. Ges. (1999), 92, 79-94.

Frisch, W., Kuhlemann, J., Dunkl, I. \& Brugel, A., 1998: Palinspastic reconstruction and topographic evolution of the eastern Alps during late Tertiary tectonic extrusion.- Tectonophysics, 297, 1-4, 1-15.

Gabrić, A., Galović, I., Sakač, K. \& Hvala, M., 1995: Mineral deposits of Istria - Some deposits of bauxite, building - stone and quartz "sand".- In: I. Vlahović \& I. Velić (Eds.), First Croatian geological congress: Excursion guide-book, Opatija, 18-21.10.1995. Institut za geološka istraživanja i Hrvatsko geološko društvo, 111 - 137, Zagreb.

Grad, K. \& Ferjančič, L. 1974. Osnovna geološka karta SFRJ. List Kranj [Kartografsko gradivo]. 1:100.000. Zvezni geološki zavod, Beograd.

Haas, J., Kovacs, S., Krystyn, L. \& Lein, R., 1995: Significance of Late Permian - Triassic facies zones in terrane reconstructions in the alpine north Pannonian domain.- Tectonophysics, 242, 1-2, 19-40.

Hamrla, M., 1959: O pogojih nastanka premogišč na kra$\mathrm{su}=\mathrm{On}$ the conditions of origin of the coal beds in the karst region.- Geologija, 5, 180-264.

Hamrla, M., 1960: K razvoju in stratigrafiji produktivnih liburnijskih plasti Primorskega krasa.- Rudarsko metalurški zbornik, 3, 203-216.

Haq, B.U., Hardenbol, J. \& Vail, P.R., 1987: Chronology of fluctuating sea levels since the Triassic.- Science, 235, 4793, 1156-1167.

Haq, B.U., Hardenbol, J. \& Vail, P.R., 1988: Mesozoic and Cenozoic chronostratigraphy and cycles of sea level change.- In: C.K. Wilgus, B.S. Hastings, C.A. Ross, H. Posamentier, J. Van Wagoner \& C.G.C. Kendall (Eds.), Sea level changes: an integrated approach: Special publication No. 42. Society for Sedimentary Geology, 71-108, Tulsa. 
Hottinger, L. \& Drobne, K., 1980: Early Tertiary conical imperforate foraminifera.- Razprave SAZU, 22, 3, $189-276$.

Jurkovšek, B., 1986: Osnovna geološka karta SFRJ. List Beljak in Ponteba [Kartografsko gradivo]. 1:100.000. Zvezni geološki zavod, Beograd.

Jurkovšek, B., Kolar-Jurkovšek, T. \& Ogorelec, B., 1997: Rezultati geološke spremljave gradbenih del na odseku avtoceste med Divačo in Kozino.- Annales, 11, 161-186.

Jurkovšek, B., Toman, M., Ogorelec, B., Šribar, L., Drobne, K., Poljak, M. \& Šribar, Lj., 1996: Formacijska geološka karta 1:50.000 južnega dela Tržaško-Komenske planote.- Inštitut za geologijo, geotehniko in geofiziko, p. 143, Ljubljana.

Košir, A. \& Otoničar, B., 1997: Diskonformnosti v zgornjekredno - paleogenskem zaporedju Jadransko - Dinarske karbonatne platforme v jugozahodni Sloveniji.- In: A. Horvat, M. Fister and N. Zupančič (Eds.), 13. Posvetovanje slovenskih geologov: Povzetki referatov, Ljubljana, 4. in 5. april, 1997. Geološki zbornik, 11, Naravoslovnotehniška fakulteta, Oddelek za geologijo, 15-16, Ljubljana.

Košir, A. \& Otoničar, B., 2001: The evolution of Upper Cretaceous and Paleogene synorogenic carbonate platforms in NW Dinaric Foreland Basin.- In: I. Dragičević \& I. Velić (Eds.), $1^{\text {st }}$ scientific meeting on carbonate platform or carbonate platforms of Dinarids: abstracts, Zagreb, Oct. $1^{\text {st }}-2^{\text {nd }} 2001$. Rudarsko-geološko-naftni fakultet, Prirodoslovnomatemetički fakultet, Institut za geološka istraživanja i Hrvatsko geološko društvo, 62-63, Zagreb.

Košir, A., 2003: Litostratigrafska revizija zgornje krede in paleogena v jugozahodni Sloveniji.- In: A. Horvat (Ed.), 16. Posvetovanje slovenskih geologov, Razprave. Poročila: Treatises. Reports (Geološki zbornik, 17). Univerza v Ljubljani, Naravoslovnotehniška fakulteta, Oddelek za geologijo, 92-98, Ljubljana.

Košir, A., 2004: Microcodium revisited: Root calcification products of terrestrial plants on carbonate-rich substrates.- Journal of sedimentary research, 74, 6, 845-857.

Magaš, N., 1965: Osnovna geološka karta SFRJ. List Cres [Kartografsko gradivo]. 1:100.000. Zvezni geološki zavod, Beograd.

Magaš, N., 1973: Osnovna geološka karta SFRJ. 1:100.000. Tolmač za list Cres.- Zvezni geološki zavod, p. 42, Beograd.

Marinčić, S. \& Matičec, D., 1991: Tektonika i kinematika deformacija na primjeru Istre.- Geološki vjesnik, 44, $257-268$
Marjanac, T. \& Ćosović, V., 2000: Tertiary depositional history of eastern Adriatic realm.- In: B. Tomljenović, D. Balen \& B. Saftić (Eds.), Pancardi 2000: fieldtrip guidebook, Dubrovnik, Croatia, 1-3.oktober 2000. Vijesti hrvatskoga geološkog društva: special issue, 37, 2, 93-103, Zagreb.

Martini, E., 1971: Standard Tertiary and Quaternary calcareous nannoplankton zonation. In: A. Farinacci (Ed.), $2^{\text {nd }}$ International conference of planktonic microfossils: proceedings, Rome. Tecnoscience, 2, 739-785.

Márton, E., 2006: Paleomagnetic evidence for Tertiary counterclockwise rotation of Adria with respect to Africa.- In: N. Pinter, G. Gyula, J. Weber, S. Stein \& D. Medak (Eds.), The Adria Microplate: GPS Geodesy, Tectonics and Hazards, NATO Science Series: IV. Earth and Environmental Sciences. Springer Netherlands, 71-80.

Márton, E., Drobne, K., Cimerman, F., Ćosović, V. \& Košir, A., 1995: Paleomagnetism of latest Maastrichtian through Oligocene rocks in Istria (Croatia), the Karst region, and S of the Sava fault (Slovenia).- In: I. Vlahović, I. Velić \& M. Šparica (Eds.), 1. hrvatski geološki kongres: Proceedings, Opatija, 18-21.10.1995. Institut za geološka istraživanja i Hrvatsko geološko društvo, 355-360.

Matičec, D., Vlahović, I., Velić, I.\& Tišljar, J., 1996: Eocene limestones overlying lower Cretaceous deposits of Western Istria (Croatia): Did some parts of present Istria form land during the Cretaceous?.- Geologia Croatica, 49, 1, 117 - 127.

Mauko, A. \& Florjančič, B., 2003: Dinosaur footprints in the Upper Turonian - Coniacian limestone in the Krnica Bay (NE Istria, Croatia) = Stopinje dinozavrov v zgornjeturonijsko - coniacijskem apnencu v zalivu Krnica (NE Istra, Hrvaška).- Geologija, 46, 1, 93-100.

Mezga, A., Bajraktarević, Z., Cvetko Tešović, B. \& Gušić, I., 2003: Dinosaur tracks as an evidence for the terrestriality in the Late Jurassic sediments of Istria, Croatia.- In: I. Vlahović (Ed.), 22 ${ }^{\text {nd }}$ IAS Meeting of Sedimentology: abstracts book, Opatija, 2003. Institute of geology, 126, Zagreb.

Miall, A.D., 1995: Collision-related froeland basins.- In: C.J. Busby \& R.V. Ingersoll (Eds.), Tectonics of sedimentary basins. Blackwell science, 393-424, Cambrige.

Mihevc, A., 2001: Speleogeneza Divaškega krasa.Založba ZRC, ZRC SAZU. Zbirka ZRC, 27, p. 180, Ljubljana. 
Mylroie, J.E. \& Carew, J.L., 1995: Karst development on carbonate islands.- In: D. A. Budd, A. H. Saller \& P. M. Harris (Eds.), Unconformities and porosity in carbonate strata. American Association of Petroleum Geologists, AAPG Memoir, 63, 55 - 76, Tulsa.

Neugebauer, J., Greiner, B. \& Appel, E., 2001: Kinematics of the Alpine-West Carpathian orogen and palaeogeographic implications.- Journal of the Geological Society, 158, 97-110.

Otoničar, B. \& Košir, A., 2001: Jurassic-Eocene geodynamic evolution of northern Dinarids: Controls on carbonate depositional systems.- In: I. Dragičević \& I. Velić (Eds.), $1^{\text {st }}$ scientific meeting on carbonate platform or carbonate platforms of Dinarids: abstracts, Zagreb, Oct. $1^{\text {st }}-2^{\text {nd }} 2001$. Rudarsko-geološko-naftni fakultet, Prirodoslovno-matemetički fakultet, Institut za geološka istraživanja i Hrvatsko geološko društvo, 59-61, Zagreb.

Otoničar, B., 1997: Macroscopic paleokarstic features in Upper Cretaceous limestones of the AdriaticDinaric Carbonate Platform (SW Slovenia).- In: P.-Y. Jeannin (Ed.), $12^{\text {th }}$ International Congress of Speleology. Swiss Speleological Society (SSS/SGH), Speleo Projects, La Chaux-de-Fonds, Switzerland, 417-420.

Otoničar, B., Košir, A., \& Ćosović, V., 2003: CretaceousTertiary paleokarst from Koromačno (Istria, NW Croatia): an example of paleokarstic denuded cave.In: I. Vlahović (Ed.), 22 ${ }^{\text {nd }}$ IAS Meeting of Sedimentology: abstracts book, Opatija, 2003. Institute of geology, 146, Zagreb.

Pamić, J., 2000: The Sava-Vardar zone (SVZ).- In: B. Tomljenović, D. Balen \& B. Saftić (Eds.), Pancardi 2000: Fieldtrip guidebook, Dubrovnik, Croatia, 1-3.oktober 2000. Vijesti hrvatskoga geološkog društva - special issue, 37, 2, 19-22, Zagreb.

Pamić, J., 2002: The Sava-Vardar Zone of the Dinarides and Hellenides versus the Vardar Ocean.- Eclogae Geologicae Helvetiae, 95, 1, 99-113.

Pamić, J., Guišić, I. \& Jelaska, V., 1998: Geodynamic evolution of the Central Dinarides.- Tectonophysics, 297, 1-4, 251-268.

Pamić, J., Gušić, I. \& Jelaska, V., 2000: Basic geological features of the Dinarids and South Tisia.- In: B. Tomljenović, D. Balen \& B. Saftić (Eds.), Pancardi 2000: Fieldtrip guidebook, Dubrovnik, Croatia, 1-3.oktober 2000. Vijesti hrvatskoga geološkog društva - special issue, 37, 2, 9-18, Zagreb.

Pavlovec, R., Knez, M., Drobne, K. \& Pavšič, J., 1991: Profiles: Košana, Sv. Trojica and Leskovec; the disintegration of the carbonate platform.- In: K. Drobne, D. Turnšek, F. Cimerman, M. Knez \& B. Ogorelec (Eds.), Introduction to the Paleogene SW Slovenia and Istria: field-trip guidebook, 69-72, Ljubljana.
Pavšič, J., 1994: Biostratigraphy of Cretaceous, Paleocene and Eocene clastics of Slovenia = Biostratigrafija krednih, paleocenskih in eocenskih klastitov Slovenije.- Razpr. - Slov. akad. znan. umet., Razr. naravosl. vede, 35, 66-84.

Placer, L., 1981: Geološka zgradba jugozahodne Slovenije $=$ Geologic structure of southwestern Slovenia.- Geologija, 24, 27 - 60.

Placer, L., 1999: Contribution to the macrotectonic subdivision of the border region between Southern Alps and External Dinarides = Prispevek k makrotektonski rajonizaciji mejnega ozemlja med Južnimi Alpami in Zunanjimi Dinaridi.- Geologija, 41, 223-255.

Placer, L., 2002: Predhodna objava rezultatov strukturnega profiliranja Kraškega roba in Istre (AC Kozina Srmin, Sečovlje) $=$ Preliminary results of structural profiling of the Kras edge and Istria (AC Kozina Srmin, Sečovlje).- Geologija, 45, 1, 277-278.

Pleničar, M., Polšak, A. \& Šikić, D., 1969: Osnovna geološka karta SFRJ. List Trst [Kartografsko gradivo]. 1:100.000. Zvezni geološki zavod, Beograd.

Pleničar, M., Polšak, A. \& Šikić, D., 1973: Osnovna geološka karta SFRJ. 1:100.000. Tolmač za list Trst.Zvezni geološki zavod, p. 68. Beograd.

Polšak, A. \& Šikić, D., 1973: Osnovna geološka karta SFRJ. 1:100.000. Tolmač za list Rovinj.- Zvezni geološki zavod, p. 51, Beograd.

Polšak, A., 1970: Osnovna geološka karta SFRJ. 1:100.000. Tolmač za list Pula.- Zvezni geološki zavod. p. 44, Beograd.

Ratschbacher, L., Frisch, W., Linzer, H.G. \& Merle, O., 1991: Lateral extrusion in the Eastern Alps 2: structural analysis.- Tectonics, 10, 2, 257-271.

Ricci Lucchi, F., 1986: The Oligocene to Recent basins of the northern Apennines.- In: P.A. Allen \& P. Homewood (Eds.), Foreland basins. Spec. Publs. Int. Ass. Sediment. - IAS. Blackwell, p. 105-139, Oxford.

Rižnar, I., 1997: Geologija okolice Postojne.- magistrsko delo, p. 78, Ljubljana.

Serra-Kiel, J. et al., 1998: Larger foraminiferal biostratigraphy of the Tethyan Paleocene and Eocene.- Bulletin De La Société Géologique De France, 169, 2, 281-299.

Sinclair, H.D., 1997: Tectonostratigraphic model for underfilled peripheral foreland basins: An Alpine perspective.- Geological Society of America Bulletin, 109, 3, 324-346.

Skaberne, D., 1987: The Paleocene megaturbidites - Anhovo.- In: E. Colizza (Ed.), E. Friuli, Karst of Gorizia and of W. Slovenia: guidebook, Trieste, $5^{\text {th }}$ and $6^{\text {th }}$ June 1987. Universita degli studi, Istituto di geologia e paleontologia, 37-45, Trieste. 
Stampfli, G. M., Mosar, J., Marquer, D., Marchant, R., Baudin T. \& Borel, G., 1998: Subduction and obduction processes in the Swiss Alps.- Tectonophysics, 296, 1-2, 159-204.

Šikić, D. \& Polšak, A., 1973: Osnovna geološka karta SFRJ. 1:100.000. Tolmač za list Labin.- Zvezni geološki zavod. p. 55, Beograd.

Šikić, D., Pleničar, M. \& Šparica, M., 1972: Osnovna geološka karta SFRJ. List Ilirska Bistrica [Kartografsko gradivo]. 1:100 000. Zvezni geološki zavod, Beograd.

Šikić, D., Polšak, A. \& Magaš, N., 1968: Osnovna geološka karta SFRJ. List Labin [Kartografsko gradivo]. 1:100.000. Zvezni geološki zavod, Beograd.

Šribar, L., 1995: Evolucija Gornjekredne Jadransko-Dinarske karbonatne platforme u jugozapadnoj Sloveniji.- magistrski rad, p. 89, Zagreb.

Tankard, A.J., 1986: On the depositional response to thrusting and lithospheric flexure: examples from the Appalachian and Rocky Mountain basins.- In: P.A. Allen and P. Homewood (Eds.), Foreland basins. IAS, Blackwell Scientific Publications, p. 369392, Oxford, Boston.

Tarlao, A., Tunis, G. \& Venturini, S., 1995: Lutetian transgression in central Istria: the Rogovići-Mečari section case.- In: I. Vlahovič, I. Velić \& M. Šparica (Eds.), 1. hrvatski geološki kongres: zbornik radova, Opatija, 18.-21. oktober 1995, Institut za geološka istraživanja i Hrvatsko geološko društvo, 613-618, Zagreb.

Tišljar, J., Vlahović, I., Matičec, D. \& Velić, I., 1995: Platformni faciesi od gornjega titona do gornjega alba $\mathrm{u}$ zapadnoj Istri i prijelaz u tempestite, klinoformne i rudistne biolititne faciese donjega cenomana u južnoj Istri (ekskurzija B).- In: I. Vlahović \& I. Velić. (Eds.), 1. hrvatski geološki kongres: vodič ekskurzija, Opatija, 18.-21.10.1995. Institut za geološka istraživanja i Hrvatsko geološko društvo, 67-110, Zagreb.

Tišljar, J., Vlahović, I., Velić, I., Matičec, D. \& Robson J., 1998: Carbonate facies evolution from the Late Albian to Middle Cenomanian in Southern Istria (Croatia): Influence of synsedimentary tectonics and extensive organic carbonate production.- Facies, 38, 137-152.

Tunis, G. \& Venturini, S., 1987: Volzana limestone and »Drenchia unit« p.so Solarie (Colovrat); Megabeds and turbidites sequence of Eastern Friuli (the italcementi quarry of Vernasso).- International syposium on the "Evolution of the karstic carbonate platform: relation with other periadriatic carbonatne platforms«: excursion guide-book, Trieste, 1.-6. 6. 1987. Universita degli studi di Trieste, Institut odi geologia e paleontologia, 3-12, Trieste.
Turnšek, D. \& Drobne, K., 1998: Paleocene corals from the northern Adriatic Platform.- In: L. Hottinger \& K. Drobne (Eds.), Paleogene shallow benthos of the Tethys. 2. Slovenska akademija znanosti in umetnosti, Dela. Znanstvenoraziskovalni center SAZU, Paleontološki inštitut Ivana Rakovca, 34, 2, 5, 129. 154, Ljubljana.

Velić, I. \& Vlahović, I., 1994: Foraminiferal assemblages in the Cenomanian of the Buzet-Savudrija area (Northwestern Istria, Croatia).- Geologia Croatica, $47,1,25-43$.

Velić, I., Tišljar, J. \& Sokač, B., 1989: The variability of thicknesses of the Barremian, Aptian and Albian carbonates as a consequence of changing depositional environments and emersion in Western Istria (Croatia, Yugoslavia).- Mem. Soc. Geol. Ital. (1987), 40, 209 - 218.

Vlahović, I., Tišljar, J., Velić, I. \& Matičec, D., 2005: Evolution of the Adriatic Carbonate Platform: Palaeogeography, main events and depositional dynamics.- Palaeogeography Palaeoclimatology Palaeoecology, 220, 3-4, 333-360.

Vrabec, M. \& Fodor, L., 2006: Late Cenozoic tectonics of Slovenia: structural styles at the Northeastern corner of the Adriatic microplate. In: N. Pinter, G. Grenerczy, J. Weber, S. Stein \& D. Medak (Eds.), The Adria microplate: GPS geodesy, tectonics and hazards. NATO Science Series, IV, Earth and Environmental Sciences. Springer, 151-168, Dordrecht.

White, W.B., 2000: Dissolution of limestone from field observations.- In: A.B. Klimchouk, D.C. Ford, A.N. Palmer \& W. Dreybrodt (Eds). Speleogenesis - Evolution of karst aquifers. National speleological society, 149-155, Huntsville.

Ziegler, P.A., Cloetingh, S. \& Van Wees, J.D., 1995: Dynamics of intra-plate compressional deformation: The Alpine foreland and other examples.- Tectonophysics, 252, 1-4, 7-59. 